Article

\title{
Does the Asset Allocation Policy Affect the Performance of Climate-Themed Funds? Empirical Evidence from the Scandinavian Mutual Funds Market
}

\author{
Lukasz Dopierała ${ }^{1, *(\mathbb{C})}$, Magdalena Mosionek-Schweda ${ }^{1}\left[\right.$ and Daria Ilczuk ${ }^{2}$ (i) \\ 1 Department of International Business, Faculty of Economics, University of Gdansk, Armii Krajowej 119/121, \\ 81-824 Sopot, Poland; magdams@ug.edu.pl \\ 2 Faculty of Economics, Graduate of the University of Gdansk, Armii Krajowej 119/121, 81-824 Sopot, Poland; \\ dariailczuk@wp.pl \\ * Correspondence: lukasz.dopierala@ug.edu.pl; Tel.: +48-58-523-1393
}

Received: 16 December 2019; Accepted: 13 January 2020; Published: 16 January 2020

\begin{abstract}
The aim of this paper is to evaluate the performance of climate-themed mutual funds, taking into consideration the structure of their asset allocation, especially their geographical focus of investment. Additionally, the influence of differences in the industry allocations on the funds' investment results is evaluated. Our analyses are based on climate-friendly mutual funds registered in Scandinavian countries (i.e., Denmark, Norway, and Sweden) during 2010-2019. To classify the analyzed funds as climate-friendly, we use the relative carbon footprint measure, which is a novelty in studies on ESG funds (meeting the environmental, social, and corporate governance criteria). In our analyses, we use the absolute performance as well as the relative performance methods. The obtained results confirm that geographical and industrial asset allocations significantly affect the performance of Scandinavian climate-friendly funds. On the basis of our studies, we may state that analyzed mutual funds do not get abnormal returns, and their performance mostly depends on the market state. Additionally, the unconditional firm size factor did not influence the return of particular portfolios, while the conditional firm size factor was significant for European, global, and North American funds. Moreover, the firm value factor was significant. Finally, the momentum factor was only significant for the emerging markets portfolio when it reached positive values.
\end{abstract}

Keywords: climate-friendly mutual funds; performance evaluation; socially responsible investment; ESG funds

\section{Introduction}

The idea of sustainable development and sustainable economy has become a new paradigm discussed widely on the international forum uniting governments and the private sector in joint activities aiming to protect the environment. There is no doubt that one of the most important steps towards a sustainable global economy was the signing of the Paris Agreement at the United Nations Framework Convention on Climate Change (it was signed by 195 countries and organizations on 12 December 2015 and entered into force on 4 November 2016). According to the article 2, the aim of this initiative is to support the global response to the threat of climate change by keeping a global temperature rise in the 21st century below 2 degrees Celsius above pre-industrial levels. Moreover, the enhancement of countries' abilities to manage the impacts of climate change and make finance flows consistent with a pathway towards low greenhouse gas emissions and climate-resilient development are other goals of the Agreement [1]. To achieve these objectives, an enormous effort has to be undertaken by governments, 
international, national, and local organizations, financial institutions, and the private sector. Financial markets also play an important role as a source of funding for activities and projects intended for environmental protection and sustainable development. As a consequence, the ideas of "green finance" and "socially responsible investment" have recently become widespread at the global level [2].

This article addresses the issue of climate-friendly (climate-themed) mutual fund performance, thus fitting into the wider context of the subject of socially responsible investment (SRI). The growing interest in SRI (frequently also called ethical investments or sustainable investments) has been observed for many years among researchers and business practitioners. Over the past decade, SRI has also become a major investment trend in the mutual fund market [3]. In the literature, SRI is defined as an investment process involved in identifying companies with high corporate social responsibility (CSR) profiles that are evaluated on the basis of environmental, social, and corporate governance (ESG) criteria. Unlike traditional investing approaches, SRI adopts a set of investment screens to select or exclude assets based on those ESG criteria [4,5]. The origins of SRI date back to 1965 when the first ethical fund was founded in Sweden [6], many years before terms such as sustainability, green finance, environmentally friendly, or socially responsible permanently entered the financial markets. This type of investing approach is not a new phenomenon on the financial markets, as its definition and objectives have evolved over the years. At the beginning, SRI strategies focused on avoiding certain investments (called "sin stocks"). These were typically companies getting significant revenues from alcohol, gambling, or tobacco and later weapons and utilities that relied on nuclear power. Nowadays, SRI rewards companies that are aware and careful about their environmental impact and treat all stakeholders well.

The aim of this paper is to evaluate the performance of climate-themed mutual funds, taking into consideration the structure of their asset allocation, especially their geographical focus of investment. Additionally, the influence of differences in the industry allocations on the funds' investment results was also evaluated. The rationale for these analyses is based on a literature review indicating the great importance of country and industry diversification to portfolio performance. Evidence that the geographic asset allocation decisions contribute to the fund or portfolio performance may be found in references [7-9]. According to some researchers, both country and industry factors are significant determinants of portfolio returns $[10,11]$. However, other studies demonstrated that geographic diversification has been relatively more important [12-15]. Nevertheless, other researchers indicated that diversification across industries may provide greater risk reduction and better performance than diversification across countries [16]. The conclusions of our research are relevant to investors, mutual or pension fund managers, and other stakeholders in the financial markets.

Our analyses are based on climate-friendly mutual funds registered in Scandinavian countries (i.e., Denmark, Norway, and Sweden) during 2010-2019. We focus on the Scandinavian market because-according to our best knowledge-a lack of research has been dedicated to SRI mutual funds domiciled in this region, while these countries are commonly known as being environmentally responsible. According to the ND-GAIN Country Index [17] that measures climate vulnerability and adaptation readiness based upon 45 indicators, Norway has been the undisputed leader for over 20 years in terms of the sensitivity of its citizens and government towards climate change, readiness for actions, and investments to prevent further degradation of nature. The top ten also includes Denmark and Sweden, which swap places at times with Finland, Iceland, New Zealand, Australia, and Switzerland. Therefore, it is justified and necessary to evaluate the investment results of climate-themed mutual funds registered in such climate-friendly countries. The meaning of the concept of climate-friendly mutual funds used in this article should also be clarified. We used this term to define mutual funds selected from data published on the Yoursri.com webpage for which Climetrics ratings were published. Secondly, we focus on data related to the so-called "funds-relative carbon footprint," which represents the estimated carbon emission per 1 Mio EUR invested [18]. Our sample consists of funds with a carbon emission indicator of less than 250 tonnes of $\mathrm{CO} 2$ per 1 Mio EUR invested (a detailed description of sample selection can be found in Section 3: Materials and Methods). It should be emphasized, however, that these are not green funds based on the meaning of 
any rating or certifying institutions (or authorities). Thus, to avoid confusing the terminology, we use the terms "climate-friendly," "climate-themed," or "environmentally responsible" funds to describe the funds analyzed in this paper.

\section{Literature Review and Research Hypotheses}

The following research hypotheses were verified in the paper:

Hypothesis 1 (H1). The geographical focus of investment significantly affects the absolute performance of Scandinavian climate-friendly funds.

Hypothesis 2 (H2). Climate-themed mutual funds investing in developed markets get abnormal returns thanks to the good portfolio selectivity skills of funds managers.

Hypothesis 3 (H3). The asset allocation differences across industries have a significant impact on the performance of climate-friendly mutual funds.

In general, our research aims to evaluate the performance of one kind of the ESG mutual funds (i.e., climate-friendly mutual funds), thus becoming part of the increasingly richer polemics in this field presented in the literature. According to the SRI investing approach and contrary to traditional investment decisions, an investor does not primarily aim to derive financial utility but also wishes to achieve non-financial utility by including assets consistent with personal and/or societal values into the portfolio [19]. This non-financial utility is unquestionable. However, no agreement has been reached among researchers regarding the financial utility of such investments. Three alternative hypotheses relate to the relative returns of socially responsible portfolios and conventional portfolios $[3,5,20,21]$. According to the "doing good while doing well" perspective, a positive association between social and financial performance exists and superior returns from investing in high-rated stocks may be achieved. Thus, the expected returns of SRI portfolio stocks are higher than the expected returns of traditional ones [22-26]. The opposite is the "doing good but not doing well" view that implies a worse financial performance of socially responsible companies because of, among other factors, transferring company resources to socially responsible activities (the expected returns of an SRI portfolio is lower than of a conventional portfolio) $[27,28]$. The last view indicates that SRI investing has no influence on the portfolio value, as CSR is not priced and the expected returns of both types of portfolios are equal [5,29]. Our results also confirm the last hypothesis because, in general, the analyzed climate-themed funds performed similarly to the traditional portfolio.

Secondly, in our analyses, we focus on the performance of mutual funds, taking into consideration the geographical allocation of their assets. Many researchers have taken into account mutual fund performance due to different criteria for the asset allocation (i.e., sectoral interests, the type of financial instruments, the size of companies, etc.) or due to the types of screens used by funds (environmental, social, ethical, etc.). However, to the authors' best knowledge, no publications have identified the influence of the geographical asset allocation on mutual fund performance. Silva and Cortez [30] evaluated the performance of US and European domiciled mutual funds that invest globally and are classified as green funds. Their findings are consistent with the "doing good but not doing well" hypothesis, as the green funds performed worse than the benchmark. However, their performance increased in crisis periods compared to non-crisis periods. These findings are consistent with results published by Varma and Nofsinger [31], who analyze US domestic equity SRI funds during 2000-2011. Areal et al. [32] consider the performance of ethical US mutual funds that adopt different ethical criteria: religious, socially responsible, and irresponsible in different market conditions (crisis and non-crisis). The authors distinguish funds that use religious screens (morally responsible funds), social screens (socially responsible funds), and unethical screens (sin funds). Their findings prove that sin funds outperform in a low-volatility market and underperform in a high-volatility market, while the performance of the morally responsible funds seems to be worse in a high-volatility market than 
in a low-volatility one. For the socially responsible funds, this relationship is the opposite. While analyzing US and European funds, Munoz et al. [33] separate green mutual funds from the overall socially responsible funds and compare the performance of these two groups. They state that green funds do not perform worse than other forms of SRI funds. In turn, Ibikunle and Steffen [34] compare the performance of European green mutual funds with black (fossil energy and natural resource) and conventional ones. According to their findings, during 1991-2014, the green funds' performance was worse than their conventional peers, while no evidence was found for differences in the performance of green and black funds. Jin [35] analyzes the industry allocation of Chinese green funds and states that they are characterized by industry concentration (instead of diversification as usual mutual funds) and invest primarily in manufacturing and small cap companies. Bauer et al. [36] also examine the asset allocation of mutual funds regarding the size of companies. They analyze ethical mutual fund performance domiciled in Germany, the United States, and the United Kingdom. Their findings show a huge exposure of German and UK funds to small cap companies, while ethical fund managers in the United States more often choose large cap companies in comparison to traditional funds. Additionally, the authors provide no evidence of a statistically significant difference in returns between ethical and conventional funds. The same conclusions can be found in later work by Bauer et al., where the ethical funds domiciled in Canada are analyzed [37]. In most of the publications presented in this study, the researchers analyzed SRI funds investing in equities. For their analyses, Derwall and Koedijk [25] use US mutual funds that invest in socially responsible fixed-income securities, concluding that these funds perform no worse than their conventional counterparts.

The evidence from the SRI mutual fund literature is predominantly focused on the US and UK markets. Few publications have presented the results of such analyses for other countries. For example, Bauer et al. [37], as mentioned above, conducted research for Canadian ethical funds. Signori [38] considers 62 ethical funds traded on the Italian market registered in Italy and also in Luxembourg. However, with the term "ethical," the author identifies not only ethical investments but also socially responsible, environmentally sustainable, ecological, and charitable investments according to the definition proposed by Assogestioni (Italian Association of Managed Savings). Signori defines a pattern of Italian ethical investments of mutual funds characterized by, among other factors, recentness of issues, options for charitable donations, the almost exclusive use of screening strategies, and the application of commissions that are no higher than the national average. Cortez et al. [39] include analyses of 88 socially responsible funds from seven European countries (i.e., Austria, Belgium, France, Germany, Italy, the Netherlands, and the UK). Schröder [40] uses a sample which consisted of 30 US SRI funds and 16 SRI funds from Germany and Switzerland. In general, their findings are consistent with the hypothesis of neutral performance of SRI funds in comparison to their conventional counterparts.

We chose the Scandinavian market, as we found a gap in the literature with this region. Some research can be found concerning particular Scandinavian markets or including Denmark, Norway, and Sweden in the broader group of analyzed countries. However, to the best of our knowledge, no publications have covered the group of countries analyzed by us. Kreander et al. [41] analyze 30 ethical and 30 non-ethical funds operated in four countries, including Sweden (the other countries are the UK, Germany, and the Netherlands), from January 1995 to December 2001. The results obtained are consistent with the hypothesis that differences in the performance of ethical and non-ethical funds are not statistically significant. Swedish and Norwegian SRI funds are included in the group of the 190 European SRI funds analyzed by Basso and Funari [42]. Their findings, for the period from 30 June 2006, to 30 June 2009, also confirm that SRI funds perform no worse than non-SRI ones. Pena and Cortez [43] examine the relationship between the risk-adjusted performance and the screening activities of 330 US and European SRI mutual funds during 2003-2014. All three Scandinavian countries are included in the European category. The general conclusion is that a negative linear relationship exists between the number of screens and the return for UK funds, and a curvilinear relationship is found for US and Scandinavian funds. For the other analyzed countries, no significant relationship is noted between screening and fund performance. The same results are obtained by Leite et al. [44] for 33 
Swedish SRI funds from November 2002 to October 2012. Moreover, authors classify analyzed funds into three groups according to their geographic focus of investment: funds investing in Sweden, in Europe, and globally. In comparison to conventional funds, SRI funds investing in Sweden and Europe perform similarly, whereas SRI funds investing globally underperform their conventional peers.

In the literature, the empirical evidence on the relationship between social and financial performance of mutual funds is inconsistent. According to Sandberg et al. [45], the heterogeneity in the SRI funds may be explained in three ways: cultural and ideological differences between countries (regions); differences in values, norms, and ideology between the different stakeholders involved in the SRI process; and the market setting in which SRI stakeholders operate. Every country has a unique legal, political, social, and institutional environment that affects the degree of development of the SRI market and the relationship between social screening and financial returns. Additionally, the methodology used and the time period under analysis also determine the results. Thus, further research is needed to complete the puzzle on this subject.

We contribute to the existing mutual fund literature by evaluating the performance of climate-friendly funds domiciled in Scandinavian countries. As previously mentioned, not much empirical evidence exists on socially responsible mutual funds, even though the Scandinavian region is a very significant player in the SRI mutual funds industry. According to data collected at the beginning of 2018, the value of global assets managed under sustainable investing was approximately USD 30.7 trillion, of which USD 14.1 trillion was in Europe [46]. SRI funds domiciled in Scandinavia include assets worth USD 925.1 billion [47]. To classify analyzed mutual funds as being climate-friendly, we use the relative carbon footprint measure, which is a novelty in studies on ESG funds. Most of researchers use databases, including labeled or certificated green or ethical funds.

The remainder of the paper is organized as follows. Section 3 offers a description of the main characteristics of our dataset, the portfolio construction procedure, and the statistical methodology used for the performance evaluation. Section 4 introduces the empirical findings on the performance of the Scandinavian climate-friendly mutual funds and discusses our findings in comparison to other research. Finally, Section 5 presents the conclusions and discussions of future research possibilities on this subject.

\section{Materials and Methods}

\subsection{Data and Portfolio Construction}

In this article, we used three data sources. To identify climate-friendly mutual funds registered on the Scandinavian market, we collected the basic information from the Yoursri.com website [48], while the financial data was obtained from the Refinitiv database and Kenneth French's online data library [49]. In our research, we only considered climate-friendly equity mutual funds that meet the following criteria: sale registration in one of the analyzed Scandinavian countries and foreign investment activity from January 2010 to August 2019. In addition, the information about the Climetrics rating reported by the Yoursri.com webpage was available for each fund as of $30 \mathrm{July,2019}$. To receive the Climetrics rating, at least $60 \%$ of a fund's assets under management must have the Climetrics company score and the latest full holdings data must be less than 12 months old. Moreover, companies are scored for their current emissions intensity relative to all other companies and for their climate management performance. Due to this information, we assumed that all those funds that received the Climetrics rating have a transparent climate policy.

Additionally, we also obtained data related to the relative carbon footprint for each fund from the Yoursri.com webpage. The relative carbon footprint expresses the greenhouse gases footprint of an investment sum. It is a normalized measure of a portfolio's contribution to climate change. It should be noted that the relative carbon footprint is measured in total carbon emissions expressed as per currency invested. The basis for a carbon footprint is the annual greenhouse gases emissions of each company within the respective fund. In addition, all direct operations, as well as energy and heat consumption, are measured in metric tonnes of carbon dioxide equivalent. The footprint is based 
on the full holdings of each fund per the most recently available Lipper data, and the corresponding greenhouse gases emission data.

To allocate company greenhouse gases emissions to a fund, the value of shares held by the fund is set in relation to the company's market capitalization. This ratio is multiplied with the emissions of the company, resulting in the emissions being "owned" by the investor. By aggregating the information on a fund level, an investment carbon footprint for the fund is established and expressed in absolute and relative terms. The described approach allows for the direct association and quantification of the emissions per investment and per fund [18]. In this article, we assumed that investors connected with the environmentally friendly approach can use this indicator to choose funds that avoid negative impacts on the climate. Therefore, we only selected funds for which the indicator was less than 250 tonnes of $\mathrm{CO}_{2}$ per 1 Mio EUR invested. It is worth emphasizing that this value represents the average value of the indicator among the funds with Climetrics ratings [50]. Our sample covered 108 funds, which we classified according to geographical areas of investment, or what should be understand as the mutual fund's investment policy declared in the prospectus. Moreover, to the group analyzed funds, we identified six major foreign markets available to Scandinavian investors: Asia and the Pacific excluding Japan (8 funds), emerging markets (4), Europe (29), global (50), Japan (7), and North America (10). It should be noted that the different number of funds in individual groups depends on the structure of the fund markets in selected Scandinavian countries. The values of relative carbon footprints for our sample are presented in Figure 1.

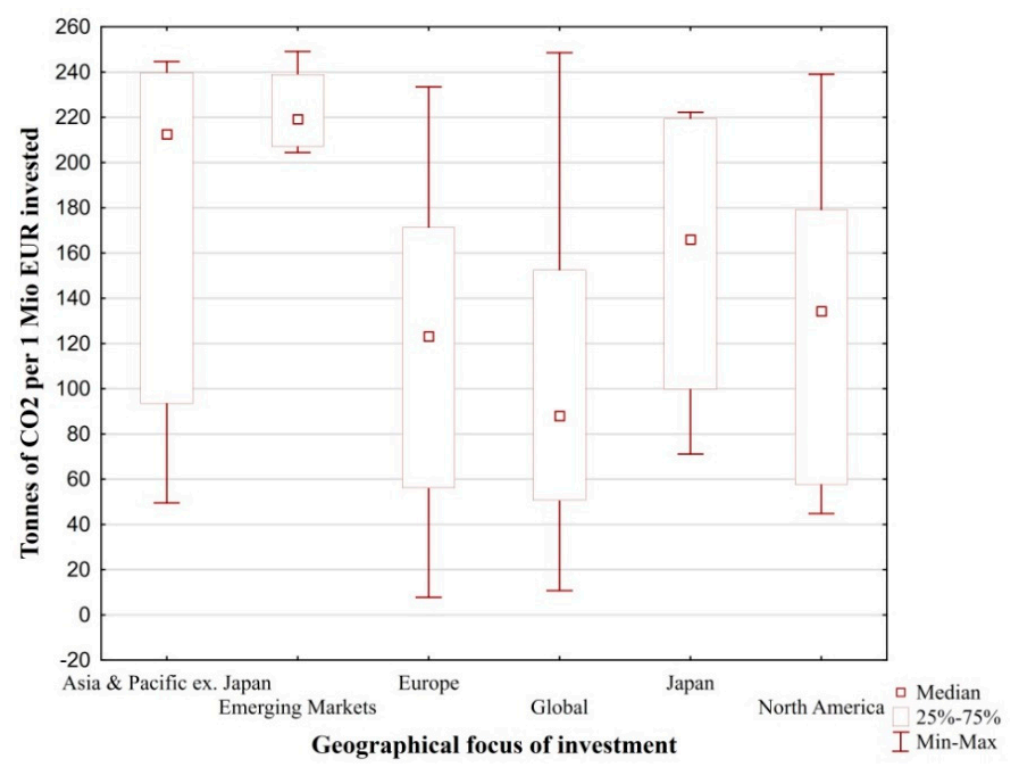

Figure 1. Relative carbon footprint for selected climate-themed funds.

To conduct the financial analysis, we used monthly valuations of fund participation units from January 2010 to August 2019 obtained from the Refinitiv database. Based on these data points, we calculated monthly continuously compounded returns for each fund to assess individual performance. Moreover, we constructed monthly continuously compounded returns for equal-weighted and value-weighted portfolios to estimate group performance. The equal-weighted portfolio return is expressed in the following way [51]:

$$
r_{e w, t}=\ln \left[\frac{1}{k} \sum_{i=1}^{k} \frac{P_{i, t}}{P_{i, t-1}}\right]
$$

where $r_{e w, t}$ is the equal-weighted, continuously compounded portfolio return over month $t, P_{i, t}$ is the value of the participation unit of the fund $i$ at the end of the month $t, P_{i, t-1}$ is that fund's participation 
unit value at the end of the month $t-1$, and the total number of funds in the portfolio equals $k$. The value-weighted portfolio is given as follows [51]:

$$
r_{v w, t}=\ln \left[\sum_{\mathrm{i}=1}^{\mathrm{k}}\left(\frac{P_{i, t}}{P_{i, t-1}} * \frac{\text { Mcap }_{i, t-1}}{\sum_{\mathrm{i}=1}^{\mathrm{k}} M_{c a p}, t-1}\right)\right]
$$

where $r_{v w, t}$ is the value-weighted, continuously compounded portfolio return over month $t$, and Mcap $_{i, t-1}$ is the market capitalization of fund $i$ at the end of month $t-1$.

From an investor's point of view, the choice of particular fund does not depend on the size of its assets. The above assumption leads to the conclusion that it is appropriate to use an equal-weighted portfolio return when assessing a fund's performance. In addition, it should be noted that a similar approach was presented both in earlier groundbreaking papers connected with socially responsible investment [52] and in the latest empirical research [30,44,53,54]. However, it is more practical to use a value-weighted portfolio return to examine the fund portfolio structure and its impact on investment results [51,55-57]. We decided to apply both of the previously mentioned approaches, which allows for a broader analysis and at the same time is a robustness test of the obtained results.

In most methods aimed to assess investment efficiency, it is necessary to assume a risk-free rate that indicates the return on assets with the minimum possible risk. In empirical research, the most common is a proxy for the risk-free rate represented by the selected money market rate or the return of short-term government securities [58]. In our research, we decided to adopt the 3-month US Treasury bill rate as a risk-free rate on the international market, which has been transformed into a continuously compounded risk-free rate using the following formula [51]:

$$
r_{f, t, 1 m}=\ln \left(1+G R_{f, t, 3 m} * \frac{3}{12}\right)^{\frac{1}{3}}
$$

where $r_{f, t, 1 m}$ represents the continuously compounded 1-month rate and $G R_{f, t, 3 m}$ is the US government 3-month Treasury rate, which was downloaded from the Refinitiv database.

\subsection{Methods}

In this article, we used two methods of assessing investment efficiency. The first method required the use of absolute performance measures, also known as risk-adjusted measures. Therefore, it was possible to examine whether the selected funds available on the Scandinavian market differed in the results achieved in relation to the risk expressed in different ways. The second method is referred to as relative performance measures, which allow the assessment of investment efficiency in relation to the market benchmark.

To apply the first method, we calculated the Sharpe ratio [59], expressed as follows:

$$
S_{i}=\frac{R_{i}-R_{f}}{\sigma_{i}}
$$

where $S_{i}$ is the Sharpe ratio of the fund $i$ in the research period, $R_{i}$ is the average return of this fund $i, R_{f}$ represents the average return of risk-free assets, and $\sigma_{i}$ is the standard deviation of the fund $i$ return. The Sharpe ratio is considered to be a classic method of assessing effectiveness; the ratio's major advantage is the simplicity of interpretation, as investment risk is measured by the volatility of rates of return. Moreover, the Sharpe ratio is commonly used in the current empirical research related to portfolio performance [60-62].

It should be noted that there are different concepts and definitions of financial risk. Therefore, we also applied indicators based on other risk measures, especially those that treat risk as a negative 
occurrence. Our study includes indicators based on upper and lower partial moments, which are expressed as follows:

$$
U P M_{i}^{n}=\frac{1}{T} \sum_{t=1}^{T} \max \left(r_{i, t}-M A R_{t}, 0\right)^{n}
$$

and

$$
L P M_{i}^{n}=\frac{1}{T} \sum_{t=1}^{T} \max \left(M A R_{t}-r_{i, t}, 0\right)^{n}
$$

where $U P M_{i}^{n}$ is the $n$-th-order upper partial moment of fund $i, L P M_{i}^{n}$ is the $n$-th-order lower partial moment of fund $i, r_{i, t}$ is the return of fund $i$ in the period $t$, and $M A R_{t}$ is the minimum accepted return in the period $t$. In addition, it is possible to subjectively define the minimum accepted return by the investor, but in our research, we assumed that it will be equal to the risk-free rate.

In further analysis, we also used two indicators based on partial moments. The first is the Sortino ratio [63], which is given by the formula:

$$
\text { Sor }_{p i}=\frac{R_{i}-M A R}{\sqrt{L P M_{i}^{2}}}
$$

where $S r_{i}$ is the Sortino ratio of the fund $i$ in the research period, MAR is the average minimum accepted return, $L P M_{i}^{2}$ is the second-order lower partial moment of fund $i$. The second of these type of indicators is the Omega ratio [64], which is expressed as follows:

$$
\Omega_{i}=\frac{U P M_{i}^{1}}{L P M_{i}^{1}}
$$

where $\Omega_{i}$ is the Omega ratio of the fund $i$ in the research period, UPM ${ }_{i}^{1}$ is the first-order upper partial moment of fund $i$, and $L P M_{i}^{1}$ is the first-order lower partial moment of fund $i$.

Moreover, we also calculated the Calmar ratio [65], which is defined as follows:

$$
\mathrm{Cal}_{i}=\frac{R_{i}-R_{f}}{-M D_{i}}
$$

where $\mathrm{Cal}_{i}$ is the Calmar ratio of the fund $\mathrm{i}$ in the research period, and $M D_{i}$ is the maximum drawdown of the fund i return. The term "maximum drawdown" is generally understood to mean the maximum loss that an investor could make when buying a financial instrument at the highest price in a given time range and selling it at the lowest price. In addition, this risk measure is sensitive to the extremely high losses incurred by the funds, and its inclusion in the measurement of effectiveness allows researchers to take into account the approach of highly risk-averse investors who avoid large negative returns more than small negative ones.

To assess the impact of geographical areas of investment on efficiency, we performed a non-parametric Kruskal-Wallis test [66]. The parametric equivalent of this test is the ANOVA. However, we did not decide to use this test in our analyses due to the variance heterogeneity in a certain group of funds. To perform the post-hoc multiple comparisons, we used a test proposed by Siegel and Castellan [67].

In the second part of our research, we applied market models to examine relative performance. It should be noted that market models are currently one of the most commonly used methods to assess socially responsible investments [68]. The first is the Capital Asset Pricing Model (CAPM) [69], which is given by the following formula:

$$
r_{i, t}-r_{f, t}=\alpha_{i}+\beta_{M, i}\left(r_{M, t}-r_{f, t}\right)+e_{i, t}
$$


where $r_{i, t}$ is the return on either the fund or the portfolio $i$ over month $t, r_{f, t}$ represents the risk-free return over month $t, r_{M, t}$ is the return on the market index over month $t, \alpha_{i}$ is the Jensens's alpha [70] representing the abnormal return of fund or portfolio $i, \beta_{M, i}$ is the market beta of fund or portfolio $i$ capturing the systematic risk exposure of this fund or portfolio, and $e_{i, t}$ is the independent disturbance term.

The CAPM assumes that the fund's results depend on the market risk, measured in relation to a benchmark that best reflects the structure of the portfolio under analysis. In our research, we adopted the appropriate Morgan Stanley Capital International (MSCI) indexes as benchmarks for funds and portfolios declaring a specific geographical area of investment. For example, for the Asia and Pacific (excluding Japan) region, it was the MSCI All Country Asia Pacific ex. Japan Price Index. Moreover, we used the MSCI All Country World Price Index as a benchmark for globally investing funds.

In a further analysis, we also applied the four-factor model, which is an extension of the CAPM, proposed by Fama and French [71] as well as Carhart [72]. The four-factor model is expressed in the following way:

$$
r_{i, t}-r_{f, t}=\alpha_{i}+\beta_{M, i}\left(r_{M, t}-r_{f, t}\right)+\beta_{S M B, i} S M B_{t}+\beta_{H M L, i} H M L_{t}+\beta_{W M L, i} W M L_{t}+e_{i, t}
$$

where $\beta_{S M B, i}, \beta_{H M L, i}, \beta_{W M L, i}$ are the additional parameters estimated in the model, $S M B_{t}$ (small minus big) represents the firm size factor, $H M L_{t}$ (high minus low) represents the firm value factor, and $W M L_{t}$ (winners minus losers) expresses the momentum factor.

The firm size factor is calculated as the average return on the three small portfolios minus the average return on the three big portfolios. The firm value factor is defined as the average return on the two value portfolios minus the average return on the two growth portfolios. The momentum factor is the equal-weight average of the returns for the two winner portfolios minus the average of the returns for the two loser portfolios. It should be noted that the data for all three factors were downloaded from Kenneth French's online data library [49].

In the last part of our research, it was possible to determine the differences in asset allocations across industries. In accordance with the Global Industry Classification Standard (GICS) [73], we identified the following 11 sectors in each fund group: consumer discretionary, consumer staples, energy, financials, health care, industrials, information technology, material, real estate, telecommunication services, and utilities. In addition, we assigned the appropriate MSCI index to a specified sector in each group and then estimated the model, which is given as follows:

$$
r_{i, t}-r_{f, t}=\alpha_{i}+\sum_{\mathbf{j}=1}^{11} \beta_{S, j, i} r_{S, j, t}+e_{i, t}
$$

where $\beta_{S, j, i}$ denotes the beta parameters of the portfolio $i$ for the sector index $j$, and $r_{S, j, t}$ represents the return from the index $j$ in the month $t$. Statistically significant values of beta parameters indicate the exposure of individual portfolios to sector indices. However, a significant coefficient does not mean that the industry is overweighted or underweighted $[35,74]$.

\section{Results and Discussion}

\subsection{Absolute Performance}

In the first step of our performance analysis, we focused on the absolute measures. More details about the descriptive statistics are presented as Appendix A. Our results indicated that most funds achieved returns higher than the risk-free rate in the long term. The average Sharpe ratio varied between individual groups and reached from 0.04 for emerging markets to 0.21 for funds investing in North America. These groups also differed in the volatility of the Sharpe ratio achieved by individual funds. The standard deviation was the highest in the globally investing funds group, which was also the largest group. Some cases also had a negative Sharpe ratio, which means that long-term return was lower than the risk-free rate for some funds in the sample. Similar relationships occurred in the case of other absolute performance measures that take into account the risk from a negative perspective. 
The results of the Spearman's rank correlation between the absolute performance ratios are presented in Table 1. We found that choosing a different risk measure does not significantly change the ranking of the funds. In addition, the rank correlation coefficients in all cases were greater than 0.95 .

Table 1. Spearman's rank correlation between absolute performance ratios.

\begin{tabular}{lcccc}
\hline & Sharpe & Sortino & Omega & Calmar \\
\hline Sharpe & 1.000 & & & \\
Sortino & 0.996 & 1.000 & & \\
Omega & 0.998 & 0.992 & 1.000 & \\
Calmar & 0.961 & 0.969 & 0.959 & 1.000 \\
\hline
\end{tabular}

Note: All the coefficients are significant at the $1 \%$ level.

The above observations may suggest that to analyze the performance, it can be sufficient to use only one of the measures, for example, the commonly used Sharpe ratio. Moreover, other researchers have supported the idea that the Sharpe ratio can be a satisfactory measure of investment performance even when the return distribution differs significantly from the Gaussian distribution [75]. However, other current authors have emphasized that the evaluation of mutual funds should not rely on a single performance measure. In addition, the use of different performance measures can bring robustness to results and possibly avoid manipulation strategies with a focus on specific measures [76].

In accordance with the above approach, the results of the Kruskal-Wallis tests and p-values for post-hoc multiple comparisons calculated on the basis of all four ratios are presented in Table 2 . Our research revealed that statistically significant differences existed between the performances of individual groups of funds. Regardless of the indicator used, the results of the Kruskal-Wallis tests provide the basis for rejecting the hypothesis about the equality of all groups.

We observed the biggest differences between funds investing in the emerging markets and in North America, as well as between funds investing in the emerging markets and globally. Further relevant differences were also noticeable between funds declaring investments in the Asia and Pacific (excluding Japan) region and funds investing in North America and globally. The average ranks for the individual groups indicated that the efficiency of the funds investing in North America and globally was significantly higher than those focused on the emerging markets and in the Asia and Pacific (excluding Japan) region. The observed differences were strong for each of the performance measures used.

It should be noted that we also identified smaller differences by comparing funds investing in Japan and North America. Statistically significant results occurred only for the Sharpe ratio and the Omega ratio. In addition, we found similar results between the funds investing in European markets and in North America. Statistically significant values were also observed for the Omega ratio and the Calmar ratio for these groups.

Due to the above results, we believe that the funds investing in developed markets, especially in North America, perform better for three main reasons. The first is, generally, higher efficiency of developed equity markets. The Sharpe ratio for MSCI indices achieved 0.0338 for Asia and Pacific (excluding Japan), 0.0005 for emerging markets, 0.0211 for Europe, 0.1194 for global market, 0.0628 for Japan, and 0.2133 for North America. In addition, the similar relationship appeared between the values of absolute performance measures for carbon intensive funds (see: Appendix B). However, the climate-themed funds achieved higher values of the Sharpe ratio than carbon intensive funds. It should be noted that the differences in absolute performance between geographical groups are higher for climate-themed funds than for carbon intensive funds (see: Figure A2). The second reason may be better knowledge of fund managers about developed markets and better information availability, which may result in the funds obtaining abnormal returns in these markets. Previous research, taking into account the geographical diversity of fund investments, has indicated that it is more difficult for managers to obtain abnormal returns in more distant and less known markets [13,77]. The third reason may be the discrepancy in the allocation of fund assets between different industries, which is 
due to the higher availability of companies based on technological innovations in developed markets. We checked both of these assumptions in further subsections.

Table 2. Kruskal-Wallis tests and $p$-values for post-hoc multiple comparisons.

\begin{tabular}{|c|c|c|c|c|c|c|}
\hline \multirow[t]{2}{*}{ Panel A: Sharpe Ratio } & \multicolumn{6}{|c|}{ Kruskal-Wallis Test: $H(5, N=108)=31.859 p=0.000$} \\
\hline & $\begin{array}{l}\text { Average } \\
\text { rank: } 27.500\end{array}$ & $\begin{array}{l}\text { Average } \\
\text { rank: } 5.000\end{array}$ & $\begin{array}{l}\text { Average } \\
\text { rank: } 47.897\end{array}$ & $\begin{array}{l}\text { Average } \\
\text { rank: } 64.360\end{array}$ & $\begin{array}{l}\text { Average } \\
\text { rank: } 34.000\end{array}$ & $\begin{array}{l}\text { Average } \\
\text { rank: } 80.100\end{array}$ \\
\hline 1. Asia \& Pacific ex. Japan & & 1.000 & 1.000 & 0.030 & 1.000 & 0.006 \\
\hline 2. Emerging Markets & 1.000 & & 0.154 & 0.004 & 1.000 & 0.001 \\
\hline 3. Europe & 1.000 & 0.154 & & 0.365 & 1.000 & 0.076 \\
\hline 5. Japan & 1.000 & 1.000 & 1.000 & 0.245 & & 0.042 \\
\hline 6. North America & 0.006 & 0.001 & 0.076 & 1.000 & 0.042 & \\
\hline \multirow[t]{3}{*}{ Panel B: Sortino Ratio } & \multicolumn{6}{|c|}{ Kruskal-Wallis Test: $\mathrm{H}(5, \mathrm{~N}=108)=29.936 p=0.000$} \\
\hline & 1 & 2 & 3 & 4 & 5 & 6 \\
\hline & $\begin{array}{c}\text { Average } \\
\text { rank: } 28.000\end{array}$ & $\begin{array}{c}\text { Average } \\
\text { rank: } 5.250\end{array}$ & $\begin{array}{c}\text { Average } \\
\text { rank: } 48.724\end{array}$ & $\begin{array}{c}\text { Average } \\
\text { rank: } 63.780\end{array}$ & $\begin{array}{c}\text { Average } \\
\text { rank: } 35.143\end{array}$ & $\begin{array}{c}\text { Average } \\
\text { rank: } 79.300\end{array}$ \\
\hline 3. Europe & 1.000 & 0.139 & & 0.592 & 1.000 & 0.117 \\
\hline 4. Global & 0.040 & 0.005 & 0.592 & & 0.352 & 1.000 \\
\hline 5. Japan & 1.000 & 1.000 & 1.000 & 0.352 & & 0.063 \\
\hline 6. North America & 0.008 & 0.001 & 0.117 & 1.000 & 0.063 & \\
\hline \multirow[t]{3}{*}{ Panel C: Omega Ratio } & \multicolumn{6}{|c|}{ Kruskal-Wallis Test: $\mathrm{H}(5, \mathrm{~N}=108)=33.358 p=0.000$} \\
\hline & 1 & 2 & 3 & 4 & 5 & 6 \\
\hline & $\begin{array}{c}\text { Average } \\
\text { rank: } 27.875\end{array}$ & $\begin{array}{c}\text { Average } \\
\text { rank: } 5.000\end{array}$ & $\begin{array}{c}\text { Average } \\
\text { rank: } 46.483\end{array}$ & $\begin{array}{c}\text { Average } \\
\text { rank: } 64.840\end{array}$ & $\begin{array}{c}\text { Average } \\
\text { rank: } 34.286\end{array}$ & $\begin{array}{c}\text { Average } \\
\text { rank: } 81.300\end{array}$ \\
\hline 1. Asia \& Pacific ex. Japan & & 1.000 & 1.000 & 0.029 & 1.000 & 0.005 \\
\hline Panel D: Calmar Ratio & $\begin{array}{l}\text { Average } \\
\text { rank: } 30.375\end{array}$ & $\begin{array}{l}\text { Average } \\
\text { rank: } 5.750\end{array}$ & $\begin{array}{l}\text { Average } \\
\text { rank: } 47.103\end{array}$ & $\begin{array}{l}\text { Average } \\
\text { rank: } 63.260\end{array}$ & $\begin{array}{l}\text { Average } \\
\text { rank: } 39.714\end{array}$ & $\begin{array}{l}\text { Average } \\
\text { rank: } 81.300\end{array}$ \\
\hline 1. Asia \& Pacific ex. Japan & & 1.000 & 1.000 & 0.087 & 1.000 & 0.009 \\
\hline 2. Emerging Markets & 1.000 & & 0.200 & 0.006 & 1.000 & 0.001 \\
\hline 3. Europe & 1.000 & 0.200 & & 0.407 & 1.000 & 0.044 \\
\hline 4. Global & 0.087 & 0.006 & 0.407 & & 0.937 & 1.000 \\
\hline 5. Japan & 1.000 & 1.000 & 1.000 & 0.937 & & 0.106 \\
\hline 6. North America & 0.009 & 0.001 & 0.044 & 1.000 & 0.106 & \\
\hline
\end{tabular}

Note: Bold values are significant at the $5 \%$ level.

\subsection{Relative Performance}

The results of the estimation of CAPM and the four-factor model for equal-weighted portfolios are presented in Table 3.

The explanatory power of the CAPM ranged from about $69 \%$ for the portfolio based on funds investing in Europe to about $95 \%$ for the portfolio constructed on the basis of emerging markets funds. The beta parameter was statistically significant for all portfolios. The portfolios based on the emerging markets and Japan were most strongly correlated with the market. The alpha parameter was significant at $5 \%$ for all the portfolios except Japan and North America.

The results of the four-factor model estimation indicated that it generally has more explanatory power, which ranged from about $72 \%$ for the Europe portfolio to $97 \%$ for the emerging markets portfolio. The beta market parameter remained statistically significant for each portfolio. The statistical 
significance of the alpha parameter decreased. It is significant at the $5 \%$ level only for the portfolio of funds investing globally. The firm size factor did not affect the return of particular portfolios; however, the firm value factor was significant. Most portfolios had a negative beta parameter related to the WML variable. The exception was the portfolio based on Asia and the Pacific (excluding Japan) where this parameter was positive. It should be noted that funds investing in each of the researched markets (excluding the Asia-Pacific region) more often included growth stocks in their investment portfolios. In addition, the momentum factor was only significant for the emerging markets portfolio, where it assumed positive values.

Table 3. Relative performance of equal-weighted portfolios.

\begin{tabular}{|c|c|c|c|c|c|c|}
\hline & $\begin{array}{c}\text { Asia \& Pacific } \\
\text { ex. Japan }\end{array}$ & Emerging Markets & Europe & Global & Japan & North America \\
\hline \multicolumn{7}{|c|}{ Panel A: CAPM Model } \\
\hline Alpha & $0.0035^{* *}$ & $0.0019^{* *}$ & $0.0048^{* *}$ & $0.0036^{* *}$ & $0.0029 *$ & 0.0019 \\
\hline Market & $0.7030^{* * *}$ & $0.8993^{* * *}$ & $0.6017^{* * *}$ & $0.6790^{* * *}$ & $0.8844^{* * *}$ & $0.8395^{* * *}$ \\
\hline Observations & 115 & 115 & 115 & 115 & 115 & 115 \\
\hline$R^{2}$ & 0.820 & 0.951 & 0.691 & 0.770 & 0.801 & 0.845 \\
\hline \multirow[t]{2}{*}{ Adj. $R^{2}$} & 0.818 & 0.951 & 0.688 & 0.768 & 0.799 & 0.843 \\
\hline & $\begin{array}{c}\text { Asia \& Pacific ex. } \\
\text { Japan }\end{array}$ & Emerging Markets & Europe & Global & Japan & North America \\
\hline \multicolumn{7}{|c|}{ Panel B: Four-Factor Model } \\
\hline Alpha & 0.0020 & 0.0002 & $0.0036^{*}$ & $0.0027^{* *}$ & $0.0031 *$ & 0.0014 \\
\hline Market & $0.7060^{* * *}$ & $0.9653^{* * *}$ & $0.6800 * * *$ & $0.6955^{* * *}$ & $0.8805^{* * *}$ & $0.8327^{* * *}$ \\
\hline SMB & -0.0280 & 0.0579 & 0.0476 & -0.0285 & -0.0019 & 0.0618 \\
\hline HML & 0.1531 ** & $-0.2193^{* * *}$ & $-0.3094^{* * *}$ & $-0.1793 * *$ & 0.0701 & $-0.1240^{* *}$ \\
\hline WML & 0.0787 & $0.2199 * * *$ & 0.0377 & 0.0511 & -0.0285 & 0.0245 \\
\hline Observations & 115 & 115 & 115 & 115 & 115 & 115 \\
\hline$R^{2}$ & 0.830 & 0.972 & 0.726 & 0.786 & 0.805 & 0.855 \\
\hline Adj. $R^{2}$ & 0.824 & 0.971 & 0.716 & 0.778 & 0.798 & 0.850 \\
\hline
\end{tabular}

Note: $* * * * *$, and $*$ indicate statistical significance at the $1 \%, 5 \%$, and $10 \%$ levels, respectively. Standard errors are corrected for autocorrelation and heteroscedasticity following Newey and West [78].

It is worth emphasizing that each model presented different results for the carbon intensive funds than for the climate-themed funds (see: Table A2). In the CAPM, the alpha parameter was significant at $5 \%$ for North America only and achieved negative values. The four-factor model indicated statistical significance of firm size factor for global and North America funds.

The results of the value-weighted portfolios are presented in Table 4. It should be noted that these results indicated similar relationships to those described above. In addition, the explanatory power of both models was lower than in the case of the equal-weighted portfolios. The CAPM suggested that it is possible to achieve abnormal returns on funds, but a better-fitting four-factor model identified that the alpha parameter was significant at $5 \%$ only for the Japan portfolio. The firm value factor had a greater impact on return results for the emerging markets and Europe portfolios. In the case of the emerging markets portfolio, the momentum factor was also significant.

The conducted estimations indicated that climate-friendly funds available on the Scandinavian market generally did not achieve abnormal returns, and their investment results depended mainly on the stage of the business cycle on the market. It should be noted that our research was partly consistent with the current results in this area. Leite et al. [44] mentioned that SRI funds operating in Sweden generally perform similarly to the market. In addition, the authors claimed that discrepancies were seen between the efficiency of the investment funds in different markets. At the same time, global funds tended to underperform, which may be connected with the poor selective abilities of global managers. However, our research did not confirm this occurrence, but indicated that it was possible for managers who invest globally or on Europe and Japanese markets to narrowly beat the market. 
Table 4. Relative performance of value-weighted portfolios.

\begin{tabular}{|c|c|c|c|c|c|c|}
\hline & $\begin{array}{l}\text { Asia \& Pacific } \\
\text { ex. Japan }\end{array}$ & $\begin{array}{l}\text { Emerging } \\
\text { Markets }\end{array}$ & Europe & Global & Japan & $\begin{array}{c}\text { North } \\
\text { America }\end{array}$ \\
\hline \multicolumn{7}{|c|}{ Panel A: CAPM Model } \\
\hline Alpha & $0.0040 * * *$ & $0.0035^{* * *}$ & $0.0046^{* *}$ & $0.0047^{* *}$ & $0.0042 * *$ & $0.0027^{*}$ \\
\hline Market & $0.7461^{* * *}$ & $0.8905^{* * *}$ & $0.5703^{* * *}$ & $0.5821^{* * *}$ & $0.8098^{* * *}$ & $0.7710^{* * *}$ \\
\hline Observations & 115 & 115 & 115 & 115 & 115 & 115 \\
\hline$R^{2}$ & 0.855 & 0.884 & 0.660 & 0.523 & 0.674 & 0.763 \\
\hline \multirow[t]{2}{*}{ Adj. $R^{2}$} & 0.854 & 0.883 & 0.657 & 0.519 & 0.671 & 0.761 \\
\hline & $\begin{array}{c}\text { Asia \& Pacific } \\
\text { ex. Japan }\end{array}$ & $\begin{array}{l}\text { Emerging } \\
\text { Markets }\end{array}$ & Europe & Global & Japan & $\begin{array}{c}\text { North } \\
\text { America }\end{array}$ \\
\hline \multicolumn{7}{|c|}{ Panel B: Four-Factor Model } \\
\hline Alpha & 0.0024 & 0.0013 & $0.0034 *$ & $0.0040 *$ & $0.0044^{* *}$ & 0.0024 \\
\hline Market & $0.7510^{* * *}$ & $0.9959^{* * *}$ & $0.6536^{* * *}$ & $0.5930^{* * *}$ & $0.8098^{* * *}$ & $0.7598^{* * *}$ \\
\hline SMB & -0.0137 & 0.0861 & 0.1200 & -0.1447 & -0.0402 & 0.0909 \\
\hline HML & $0.1310 *$ & $-0.4164^{* * *}$ & $-0.3219^{* *}$ & -0.1855 & $-0,0207$ & $-0,0477$ \\
\hline WML & 0.0984 & $0.2923^{* * *}$ & 0.0258 & 0.0194 & -0.0492 & 0.0612 \\
\hline Observations & 115 & 115 & 115 & 115 & 115 & 115 \\
\hline$R^{2}$ & 0.864 & 0.932 & 0.701 & 0.538 & 0.676 & 0.771 \\
\hline Adj. $R^{2}$ & 0.859 & 0.930 & 0.690 & 0.521 & 0.664 & 0.763 \\
\hline
\end{tabular}

Note: ${ }^{* * *}, * *$, and $*$ indicate statistical significance at the $1 \%, 5 \%$, and $10 \%$ levels, respectively. Standard errors are corrected for autocorrelation and heteroscedasticity following Newey and West [78].

The exposure of the climate-friendly funds on the size factor was insignificant, which contradicts previous research focused on other markets [34,35]. It is possible that the discrepancies between the index return and the funds return were generated by selecting growth stocks in portfolios or using the momentum effect. These strategies can be effective, especially in small and medium markets, as reported in the previous literature findings $[79,80]$. Our research also suggested that fund management styles may be different depending on geographical asset allocations.

It should be emphasized that the stage of the business cycle has an important impact on the performance of the funds. In addition, several authors have indicated that SRI funds perform better during a crisis, when it is possible to outperform the market. However, funds achieve average results or even underperform the market in non-crisis periods [30,33,81,82]. In our research, the alpha parameter confirmed the relationship mentioned above because we mainly covered periods of increases in the market, in particular in the North America region. However, only short recession periods appeared in the other markets.

\subsection{Asset Allocation Differences across Industries}

As mentioned in the previous subsections, the differences in the absolute performance of the climate-friendly funds depend mainly on their market exposure. Therefore, the exposure of both the equal-weighted portfolios and the value-weighted portfolios on the sector indices is presented in Table 5 .

It should be noted that in both types of portfolio cases, the models had a relatively high explanatory power (adjusted $R^{2}$ for the equal-weighted portfolios from approximately $86 \%$ to $97 \%$ and for the value-weighted portfolios, from $69 \%$ to $92 \%$ ). In addition, our analysis of the geographical regions of investments identified that their exposure levels to some sector indices were different. Moreover, the returns of most portfolios were not dependent on the following indices: energy, telecommunication services, and utilities. It should be emphasized that the exception was global funds, because the correlation with the utilities index was negative in that case. Therefore, the above results suggested that the majority of the funds avoided the industries connected with a direct negative impact on the climate throughout the entire period of activity. 
Table 5. Industry analysis of portfolio returns.

\begin{tabular}{|c|c|c|c|c|c|c|}
\hline & $\begin{array}{l}\text { Asia \& Pacific } \\
\text { ex. Japan }\end{array}$ & $\begin{array}{l}\text { Emerging } \\
\text { Markets }\end{array}$ & Europe & Global & Japan & $\begin{array}{c}\text { North } \\
\text { America }\end{array}$ \\
\hline \multicolumn{7}{|c|}{ Panel A: Equal-Weighted Portfolio } \\
\hline Alpha & 0.0020 & -0.0009 & 0.0008 & 0.0006 & 0.0013 & 0.0003 \\
\hline Consumer Discretionary & $0.1879^{* * *}$ & $0.1224^{* * *}$ & $0.1563^{* * *}$ & $0.1311^{* * *}$ & $-0.0945 *$ & $0.1791 * *$ \\
\hline Consumer Staples & -0.0808 & $0.2654^{* * *}$ & 0.0409 & -0.0292 & $0.1963^{* * *}$ & 0.0510 \\
\hline Energy & 0.0848 & $0.0824^{* * *}$ & 0.0258 & $0.0716^{* *}$ & -0.0202 & 0.0591 \\
\hline Financials & 0.0781 & 0.0299 & $0.1308^{* * *}$ & 0.0238 & $0.1531^{* * *}$ & $0.1147 *$ \\
\hline Health Care & 0.0007 & $0.0554^{* *}$ & $0.1082 * * *$ & $0.2770^{* * *}$ & $0.1370^{* * *}$ & $0.1906^{* * *}$ \\
\hline Industrials & $0.3121 * * *$ & $0.1710^{* * *}$ & $0.2399^{* * *}$ & 0.1248 & $0.2026^{* *}$ & 0.0594 \\
\hline Information Technology & $0.2492^{* * *}$ & $0.1809^{* * *}$ & $0.0904^{* * *}$ & $0.1694^{* * *}$ & $0.0990^{* *}$ & $0.2585^{* * *}$ \\
\hline Material & $-0.2544^{* * *}$ & 0.0085 & 0.0219 & $-0.1266^{* *}$ & 0.0828 & -0.0699 \\
\hline Real Estate & $0.2434^{* * *}$ & 0.0409 & $0.1162^{* * *}$ & $0.2335^{* * *}$ & -0.0097 & 0.0163 \\
\hline Telecommunication Services & -0.0389 & 0.0398 & -0.0489 & $0.0964^{* * *}$ & 0.0218 & -0.0274 \\
\hline Utilities & -0.0074 & 0.0459 & 0.0083 & $-0.2490^{* * *}$ & 0.0247 & -0.0625 \\
\hline Observations & 115 & 115 & 115 & 115 & 115 & 115 \\
\hline$R^{2}$ & 0.877 & 0.968 & 0.949 & 0.884 & 0.896 & 0.876 \\
\hline \multirow[t]{2}{*}{ Adj. $R^{2}$} & 0.864 & 0.965 & 0.944 & 0.872 & 0.885 & 0.863 \\
\hline & $\begin{array}{l}\text { Asia \& Pacific } \\
\text { ex. Japan }\end{array}$ & $\begin{array}{l}\text { Emerging } \\
\text { Markets }\end{array}$ & Europe & Global & Japan & $\begin{array}{c}\text { North } \\
\text { America }\end{array}$ \\
\hline \multicolumn{7}{|c|}{ Panel B: value-weighted portfolio } \\
\hline Alpha & 0.0024 * & -0.0003 & 0.0010 & 0.0008 & 0.0027 & 0.0013 \\
\hline Consumer Discretionary & $0.2141^{* * *}$ & $0.1880^{* * *}$ & $0.1187^{* * *}$ & $0.1923 * * *$ & -0.0992 & $0.1703 *$ \\
\hline Consumer Staples & -0.0320 & $0.2298^{* * *}$ & -0.0747 & -0.1103 & $0.1577 * *$ & 0.0696 \\
\hline Energy & 0.0777 & 0.0068 & 0.0173 & $0.1062 * *$ & $-0.0627 *$ & 0.0638 \\
\hline Financials & -0.0179 & 0.0635 & $0.0737^{* * *}$ & 0.0556 & $0.1549^{* *}$ & $0.1554 *$ \\
\hline Health Care & -0.0314 & 0.0481 & $0.1233 * * *$ & $0.2736^{* * *}$ & $0.2089 * * *$ & $0.1818^{* * *}$ \\
\hline Industrials & $0.2605^{* * *}$ & $0.2520 * * *$ & $0.2871 * * *$ & 0.0312 & $0.2784^{* *}$ & 0.0726 \\
\hline Information Technology & $0.2937^{* * *}$ & $0.1921^{* * *}$ & $0.0953 * *$ & $0.2964^{* * *}$ & 0.0782 & $0.1908^{* * *}$ \\
\hline Material & $-0.2151 * * *$ & -0.0323 & 0.0089 & $-0.2343^{* * *}$ & 0.0223 & $-0.1099 * *$ \\
\hline Real Estate & $0.2886^{* * *}$ & 0.0220 & $0.2134^{* * *}$ & $0.1609 * *$ & -0.0620 & 0.0088 \\
\hline Telecommunication Services & -0.0211 & 0.0430 & -0.0046 & $0.1169 * *$ & 0.0048 & -0.0486 \\
\hline Utilities & -0.0069 & 0.0466 & -0.0305 & $-0.2864 * * *$ & 0.0502 & -0.0474 \\
\hline Observations & 115 & 115 & 115 & 115 & 115 & 115 \\
\hline$R^{2}$ & 0.908 & 0.922 & 0.928 & 0.716 & 0.748 & 0.800 \\
\hline Adj. $R^{2}$ & 0.898 & 0.914 & 0.920 & 0.685 & 0.721 & 0.779 \\
\hline
\end{tabular}

Note: ${ }^{* * *}, * *$, and $*$ indicate statistical significance at the $1 \%, 5 \%$, and $10 \%$ levels, respectively. Standard errors are corrected for autocorrelation and heteroscedasticity following Newey and West [78].

Our research also indicated the differences between the portfolios based on the funds, which were characterized by high and low absolute performance. In addition, it should be noted that the portfolio based on funds investing in the North America region, which achieved the highest absolute performance, depended mainly on the information technology and health care indices. In the case of portfolios based on funds with the lowest absolute performance (emerging markets and Asia \& the Pacific ex. Japan), the health care index was statistically insignificant. In addition, the low absolute performance portfolios were heavily exposed to the industrials index, which was statistically insignificant for the high absolute return portfolios. Therefore, our analysis indicated that it was possible to invest in advanced technology sectors and achieve high results and meet the criteria for climate protection at the same time. It should be emphasized that the replacement of industries that negatively affect the climate with technologically advanced and climate-friendly industries may not have a negative impact on investment results, but it may even improve them. This occurrence is also confirmed by industry analysis of carbon intensive funds (see: Table A3).

Our results confirmed previous observations reported by Busse and Tong [83], who claimed that the industry selection accounts for a full third of fund performance and that the industry-selection skill drives persistence in fund performance. At the same time, our industry analysis was consistent 
with the findings of Jin and Han [35], who showed that green funds industry preference has a positive correlation with innovation indicators in the Chinese market.

\subsection{Robustness Tests}

To test the robustness of the results, an analysis was developed using the conditional models, which are an extension of classic models proposed by Ferson and Schadt [84] and Christopherson et al. [85].

The conditional CAPM is given by the following formula:

$$
r_{i, t}-r_{f, t}=\alpha_{0 i}+\alpha_{i}^{\prime} z_{t-1}+\beta_{0 M, i}\left(r_{M, t}-r_{f, t}\right)+\beta_{M, i}^{\prime}\left(r_{M, t}-r_{f, t}\right) z_{t-1}+e_{i, t}
$$

while the conditional four-factor model is expressed in the following way:

$$
\begin{aligned}
r_{i, t}-r_{f, t}=\alpha_{0 i}+ & \alpha_{i}^{\prime} z_{t-1}+\beta_{0 M, i}\left(r_{M, t}-r_{f, t}\right)+\beta_{M, i}^{\prime}\left(r_{M, t}-r_{f, t}\right) z_{t-1}+\beta_{0 S M B, i} S M B_{t} \\
& +\beta_{S M B, i}^{\prime} S M B_{t} z_{t-1}+\beta_{0 H M L, i} H M L_{t}+\beta_{H M L, i}^{\prime} H M L_{t} z_{t-1} \\
& +\beta_{0 W M L, i} W M L_{t}+\beta_{W M L, i}^{\prime} W M L_{t} z_{t-1}+e_{i, t}
\end{aligned}
$$

where $z_{t-1}$ represents the vector of lagged information variables measured as deviations from their averages $\left(z_{t-1}=Z_{t-1}-E(Z)\right)$. The parameters $\alpha_{i^{\prime}}^{\prime}, \beta_{M, i^{\prime}}^{\prime} \beta_{S M B, i^{\prime}}^{\prime} \beta_{H M L, i^{\prime}}^{\prime} \beta_{W M L, i}^{\prime}$ capture the response of the conditional alpha and conditional betas to the lagged information variables. As predetermined information variables containing information on economic conditions, we consider the short-term rate and a default spread for each market following Silva and Cortez [30]. The results of the conditional

\begin{tabular}{|c|c|c|c|c|c|c|}
\hline & $\begin{array}{c}\text { Asia \& Pacific } \\
\text { ex. Japan }\end{array}$ & $\begin{array}{l}\text { Emerging } \\
\text { Markets }\end{array}$ & Europe & Global & Japan & $\begin{array}{c}\text { North } \\
\text { America }\end{array}$ \\
\hline \multicolumn{7}{|c|}{ Panel A: CAPM Model } \\
\hline Alpha & $0.0035^{* *}$ & $0.0019^{* *}$ & $0.0047^{* *}$ & $0.0036^{* *}$ & $0.0029 *$ & 0.0019 \\
\hline Alpha' & 0.0013 & -0.0013 & -0.0012 & -0.0010 & $0.0037 *$ & -0.0033 * \\
\hline Market & $0.7083^{* * *}$ & $0.8982 * * *$ & $0.6091^{* * *}$ & $0.6804^{* * *}$ & $0.8857^{* * *}$ & $0.8323^{* * *}$ \\
\hline Market' & 0.0811 & $-0.0654^{* * *}$ & 0.0731 & -0.0031 & -0.0442 & 0.0385 \\
\hline Observations & 115 & 115 & 115 & 115 & 115 & 115 \\
\hline$R^{2}$ & 0.825 & 0.953 & 0.694 & 0.771 & 0.804 & 0.848 \\
\hline \multirow[t]{2}{*}{ Adj. $R^{2}$} & 0.820 & 0.952 & 0.685 & 0.765 & 0.799 & 0.844 \\
\hline & $\begin{array}{l}\text { Asia \& Pacific } \\
\text { ex. Japan }\end{array}$ & $\begin{array}{l}\text { Emerging } \\
\text { Markets }\end{array}$ & Europe & Global & Japan & $\begin{array}{c}\text { North } \\
\text { America }\end{array}$ \\
\hline \multicolumn{7}{|c|}{ Panel B: Four-Factor Model } \\
\hline Alpha & 0.0018 & 0.0004 & $0.0038 *$ & 0.0024 * & $0.0031 *$ & 0.0010 \\
\hline Alpha' & -0.0006 & $-0.0015 *$ & 0.0030 & -0.0024 & $0,0048^{*}$ & $-0.0061^{* *}$ \\
\hline Market & $0.7167^{* * *}$ & $0.9639^{* * *}$ & $0.6887^{* * *}$ & $0.6899^{* * *}$ & $0.8774^{* * *}$ & $0.8178^{* * *}$ \\
\hline Market' & 0.0912 & -0.0329 & 0.0651 & 0.0157 & -0.0324 & 0,0195 \\
\hline SMB & -0.0229 & 0.0571 & 0.08227 & -0.0295 & -0.0011 & 0.0883 \\
\hline $\mathrm{SMB}^{\prime}$ & 0.0161 & -0.0640 & 0.4596 ** & $0.3368^{* * *}$ & -0.2250 & $0.2280^{* *}$ \\
\hline HML & 0.1350 * & $-0.2405^{* * *}$ & $-0.2858^{* * *}$ & $-0.1731^{* *}$ & 0.0714 & -0.1254 * \\
\hline HML' & 0.2236 & $-0,0136$ & 0.1080 & -0.1357 & 0.0257 & -0.1573 \\
\hline WML & 0.0824 & $0.1927^{* * *}$ & 0.0498 & 0.0610 & -0.0492 & 0.0407 \\
\hline WML' & 0.1022 & 0.0232 & -0.1014 & $-0,1764$ & 0.1674 & -0.0819 \\
\hline Observations & 115 & 115 & 115 & 115 & 115 & 115 \\
\hline$R^{2}$ & 0.840 & 0.973 & 0.741 & 0.795 & 0.814 & 0.866 \\
\hline Adj. $R^{2}$ & 0.826 & 0.970 & 0.719 & 0.778 & 0.798 & 0.855 \\
\hline
\end{tabular}
models are presented in Tables 6 and 7.

Table 6. Conditional Capital Asset Pricing Model (CAPM) and the four-factor model for equal-weighted portfolios.

Note: ${ }^{* * *}, * *$, and $*$ indicate statistical significance at the $1 \%, 5 \%$, and $10 \%$ levels, respectively. Standard errors are corrected for autocorrelation and heteroscedasticity following Newey and West [78]. 
Table 7. Conditional CAPM and a four-factor model for value-weighted portfolios.

\begin{tabular}{|c|c|c|c|c|c|c|}
\hline & $\begin{array}{c}\text { Asia \& Pacific } \\
\text { ex. Japan }\end{array}$ & $\begin{array}{l}\text { Emerging } \\
\text { Markets }\end{array}$ & Europe & Global & Japan & $\begin{array}{c}\text { North } \\
\text { America }\end{array}$ \\
\hline \multicolumn{7}{|c|}{ Panel A: CAPM Model } \\
\hline Alpha & $0.0040 * * *$ & $0.0035^{* *}$ & $0.0045^{* *}$ & $0.0047^{* *}$ & $0.0042 * *$ & $0.0027^{*}$ \\
\hline Alpha' & 0.0006 & -0.0001 & $-0.0059 *$ & -0.0031 & 0.0020 & $-0.0043^{* *}$ \\
\hline Market & $0.7499^{* * *}$ & $0.8893^{* * *}$ & $0.5808^{* * *}$ & $0.5806^{* * *}$ & $0.8131^{* * *}$ & $0.7604^{* * *}$ \\
\hline Market' & 0.0583 & $-0.0904^{* *}$ & 0.0562 & 0.0242 & -0.0919 & 0.0550 \\
\hline Observations & 115 & 115 & 115 & 115 & 115 & 115 \\
\hline$R^{2}$ & 0.858 & 0.888 & 0.670 & 0.527 & 0.677 & 0.770 \\
\hline \multirow[t]{2}{*}{ Adj. $R^{2}$} & 0.854 & 0.885 & 0.661 & 0.514 & 0.669 & 0.764 \\
\hline & $\begin{array}{l}\text { Asia \& Pacific } \\
\text { ex. Japan }\end{array}$ & $\begin{array}{l}\text { Emerging } \\
\text { Markets }\end{array}$ & Europe & Global & Japan & $\begin{array}{c}\text { North } \\
\text { America }\end{array}$ \\
\hline \multicolumn{7}{|c|}{ Panel B: Four-Factor Model } \\
\hline Alpha & 0.0021 & 0.0019 * & $0.0037 *$ & 0.0032 & $0.0042 * *$ & 0.0019 \\
\hline Alpha' & -0.0013 & -0.0008 & 0.0005 & -0.0061 & 0.0022 & $-0.0071^{* *}$ \\
\hline Market & $0.7614^{* * *}$ & $0.9930^{* * *}$ & $0.6643 * * *$ & $0.5817^{* * *}$ & $0.7955^{* * *}$ & 0.7419 *** \\
\hline Market' & 0.0677 & -0.0056 & 0.0252 & 0.0611 & -0.0893 & 0.0261 \\
\hline SMB & -0.0161 & 0.0939 & 0.1459 & -0.1484 & -0.0503 & $0.1215 *$ \\
\hline $\mathrm{SMB}^{\prime}$ & 0.0450 & -0.2924 & $0.5446^{* *}$ & $0.5497^{* * *}$ & -0.1357 & $0.2625^{* *}$ \\
\hline HML & 0.1123 & $-0.4622 * * *$ & $-0.2929 * *$ & -0.1953 & 0.0224 & -0.0501 \\
\hline HML' & 0.1981 & -0.2758 & 0.3276 & -0.2732 & 0.3149 & -0.1842 \\
\hline WML & 0.1011 & $0.2260^{* * *}$ & 0.0254 & 0.0279 & -0.0545 & 0.0680 \\
\hline WML' & 0.1050 & 0.1218 & -01244 & -0.2038 & 0.2261 * & -0.0930 \\
\hline Observations & 115 & 115 & 115 & 115 & 115 & 115 \\
\hline$R^{2}$ & 0.871 & 0.938 & 0.736 & 0.563 & 0.691 & 0.787 \\
\hline Adj. $R^{2}$ & 0.859 & 0.932 & 0.714 & 0.525 & 0.664 & 0.769 \\
\hline
\end{tabular}

Note: ${ }^{* * *}, * *$, and $*$ indicate statistical significance at the $1 \%, 5 \%$, and $10 \%$ levels, respectively. Standard errors are corrected for autocorrelation and heteroscedasticity following Newey and West [78].

The explanatory power of the conditional and unconditional models is similar. General conclusions from conditional models are close to those obtained from unconditional models. However, conditional models indicated the statistical significance of the positive conditional SMB factor for European, global, and North American funds. It suggests that, on those markets, the climate-themed fund managers dynamically expose the fund portfolio on firm size factor by using public information.

\section{Conclusions}

As previously mentioned, the literature considering the different issues of SRI and ESG funds, including climate-friendly or green mutual funds, is growing. However, the results of various studies are often ambiguous and even contradictory. These differences may result from the methodology used, the analyzed period, or the countries/markets chosen for analyzes. Our research makes a contribution to the existing literature by analyzing Scandinavian climate-friendly mutual funds. The aim of our study was to evaluate fund performance, taking into consideration the geographical focus of the investment and the sectoral asset allocation. The obtained results confirm that the geographical asset allocation significantly affects the performance of Scandinavian climate-friendly funds (which is consistent with the $\mathrm{H} 1$ research hypothesis). Similarly, the asset allocation differences across industries have a significant impact on a fund's investment results. Thus, the H3 research hypothesis may be positively verified. On the basis of our studies, we may also state that, in general, analyzed mutual funds do not get abnormal returns, and their performance mostly depends on the market state. Good portfolio selectivity skills of funds managers were insignificant in terms of the performance level, even in the case of the climate-themed mutual funds investing in developed markets (thus, the H2 hypothesis was negatively verified). Additionally, the unconditional firm size factor did not influence the return 
of particular portfolios, while the conditional SMB factor was significant for European, global, and North American funds. Moreover, the firm value factor was significant. Finally, the momentum factor was only significant for the emerging markets portfolio, as it reached positive values.

Our results are partly consistent with the results of Leite et al. [44] who proved that SRI funds registered in Sweden generally perform similarly to the market. The authors also demonstrated discrepancies between the efficiency of the investment funds in different markets. Secondly, they observed that global funds tended to underperform and justified this with the poor selective abilities of global managers. However, our research indicated that managers investing globally or on Europe and Japanese markets may narrowly beat the market. Additionally, we confirmed that SRI funds perform better during a crisis, and achieve average results or underperform the market in non-crisis periods which is consistent with several prior studies [30,33,81,82]. As far as the industry factor is concerned, our results are consistent with the findings of Busse and Tong [83] who proved the importance of industry-selection skill for fund performance and with the studies of Jin and Han [35] on the positive correlation between that green funds preference and innovation indicators in the Chinese market. Finally, we revealed that the unconditional firm size factor did not influence the return of the climate-friendly funds, which is in contradiction to previous research focused on other markets [34,35].

As was indicated in the Introduction, geographic and/or industry diversification is considered as an important determinant of portfolio performance affecting the risk and return of an investment. Thus, aiming to evaluate the performance of the equity, climate-themed, Scandinavian mutual funds, we considered both geographic and industry diversification. The conclusions of our research are relevant to investors, fund managers, and other stakeholders in the financial markets.

We are aware of the limitations in our analysis. First, we only analyzed equity mutual funds. Thus, further analyses could be conducted for funds focused on fixed-income or mixed assets. Second, studies could be expanded by considering other markets than Scandinavia. Different methodologies could also be used. For example, a DEA approach or market timing models may be appropriate for such analyses. Finally, our database only includes existing funds. Results of analyses based on databases containing liquidated funds may make a significant contribution to the ongoing discussion on the financial and social performance of ESG mutual funds.

Author Contributions: conceptualization, Ł.D., M.M.-S.; methodology, Ł.D., M.M.-S.; validation, Ł.D., D.I.; formal analysis, Ł.D., M.M.-S. and D.I.; investigation, Ł.D., M.M.-S. and D.I.; resources, Ł.D., M.M.-S. and D.I.; writing-original draft preparation, Ł.D., M.M.-S. and D.I.; writing-review and editing, Ł.D., M.M.-S. and D.I.; visualization, Ł.D., M.M.-S. and D.I. All authors have read and agreed to the published version of the manuscript.

Funding: This research received no external funding.

Acknowledgments: We would like to thank anonymous referees for their valuable comments. The data used in this paper were collected from the Refinitiv database according to a partnership agreement between the University of Gdansk, Poland, and Refinitiv.

Conflicts of Interest: The authors declare no conflict of interest.

\section{Appendix A}

Table A1. Absolute performance ratios-descriptive statistics.

\begin{tabular}{lccccccc}
\hline & Mean & Median & Min & Max & SD & Skewness & Kurtosis \\
\hline \multicolumn{7}{c}{ Panel A: Sharpe Ratio } \\
\hline 1. Asia \& Pacific ex. Japan & 0.1083 & 0.1198 & 0.0529 & 0.1625 & 0.0387 & -0.3098 & -1.5567 \\
2. Emerging Markets & 0.0408 & 0.0312 & 0.0243 & 0.0767 & 0.0213 & 1.6919 & 2.7666 \\
3. Europe & 0.1486 & 0.1446 & 0.0597 & 0.2493 & 0.0429 & 0.2623 & -0.0949 \\
4. Global & 0.1790 & 0.1851 & -0.0273 & 0.3294 & 0.0650 & -0.4303 & 1.0833 \\
5. Japan & 0.1161 & 0.0854 & 0.0423 & 0.2005 & 0.0541 & 0.4624 & -1.2755 \\
6. North America & 0.2113 & 0.2225 & 0.1265 & 0.2698 & 0.0440 & -0.4498 & -0.5523 \\
\hline
\end{tabular}


Table A1. Cont.

\begin{tabular}{|c|c|c|c|c|c|c|c|}
\hline & Mean & Median & Min & Max & SD & Skewness & Kurtosis \\
\hline \multicolumn{8}{|c|}{ Panel B: Sortino Ratio } \\
\hline 1. Asia \& Pacific ex. Japan & 0.1572 & 0.1746 & 0.0718 & 0.2471 & 0.0612 & -0.2076 & -1.5446 \\
\hline 2. Emerging Markets & 0.0569 & 0.0431 & 0.0338 & 0.1075 & 0.0299 & 1.7287 & 2.9274 \\
\hline 3. Europe & 0.2243 & 0.2169 & 0.0835 & 0.4370 & 0.0765 & 0.6847 & 0.6832 \\
\hline 4. Global & 0.2740 & 0.2691 & -0.0330 & 0.6317 & 0.1142 & 0.2509 & 1.3555 \\
\hline 5. Japan & 0.1740 & 0.1197 & 0.0576 & 0.3053 & 0.0907 & 0.5280 & -1.5245 \\
\hline 6. North America & 0.3251 & 0.3401 & 0.1675 & 0.4446 & 0.0828 & -0.3503 & -0.4646 \\
\hline \multicolumn{8}{|c|}{ Panel C: Omega Ratio } \\
\hline 1. Asia \& Pacific ex. Japan & 1.3330 & 1.3749 & 1.1492 & 1.5274 & 0.1286 & -0.2422 & -1.2965 \\
\hline 2. Emerging Markets & 1.1161 & 1.0851 & 1.0660 & 1.2282 & 0.0661 & 1.7599 & 3.0590 \\
\hline 3. Europe & 1.4631 & 1.4444 & 1.1582 & 1.8487 & 0.1590 & 0.4817 & 0.0161 \\
\hline 4. Global & 1.6078 & 1.6216 & 0.9266 & 2.3629 & 0.2593 & 0.2662 & 1.0469 \\
\hline 5. Japan & 1.3660 & 1.2496 & 1.1129 & 1.6996 & 0.1994 & 0.6833 & -0.9761 \\
\hline 6. North America & 1.7241 & 1.7733 & 1.4137 & 1.9657 & 0.1705 & -0.3348 & -0.8649 \\
\hline \multicolumn{8}{|c|}{ Panel D: Calmar Ratio } \\
\hline 1. Asia \& Pacific ex. Japan & 0.0192 & 0.0210 & 0.0080 & 0.0312 & 0.0077 & -0.1548 & -1.0694 \\
\hline 2. Emerging Markets & 0.0065 & 0.0049 & 0.0032 & 0.0131 & 0.0039 & 1.7186 & 3.0084 \\
\hline 3. Europe & 0.0266 & 0.0237 & 0.0091 & 0.0580 & 0.0100 & 1.0136 & 1.8921 \\
\hline 4. Global & 0.0365 & 0.0314 & -0.0030 & 0.1072 & 0.0198 & 1.0871 & 2.2782 \\
\hline 5. Japan & 0.0244 & 0.0168 & 0.0070 & 0.0501 & 0.0149 & 0.8807 & -0.7841 \\
\hline 6. North America & 0.0452 & 0.0464 & 0.0194 & 0.0676 & 0.0130 & -0.3801 & 0.3409 \\
\hline
\end{tabular}

\section{Appendix B Performance of Carbon Intensive Funds}

This appendix presents the results of carbon intensive funds' performance. For this analysis, we selected funds characterized by the relative carbon footprint higher than 250 tonnes of $\mathrm{CO} 2$ per 1 Mio EUR invested. This sample covered 106 funds, which we classified according to geographical areas of investment: Asia and the Pacific excluding Japan (19 funds), emerging markets (39), Europe (15), global (27), Japan (2), and North America (4). The values of relative carbon footprint for carbon intensive funds are presented in Figure A1.

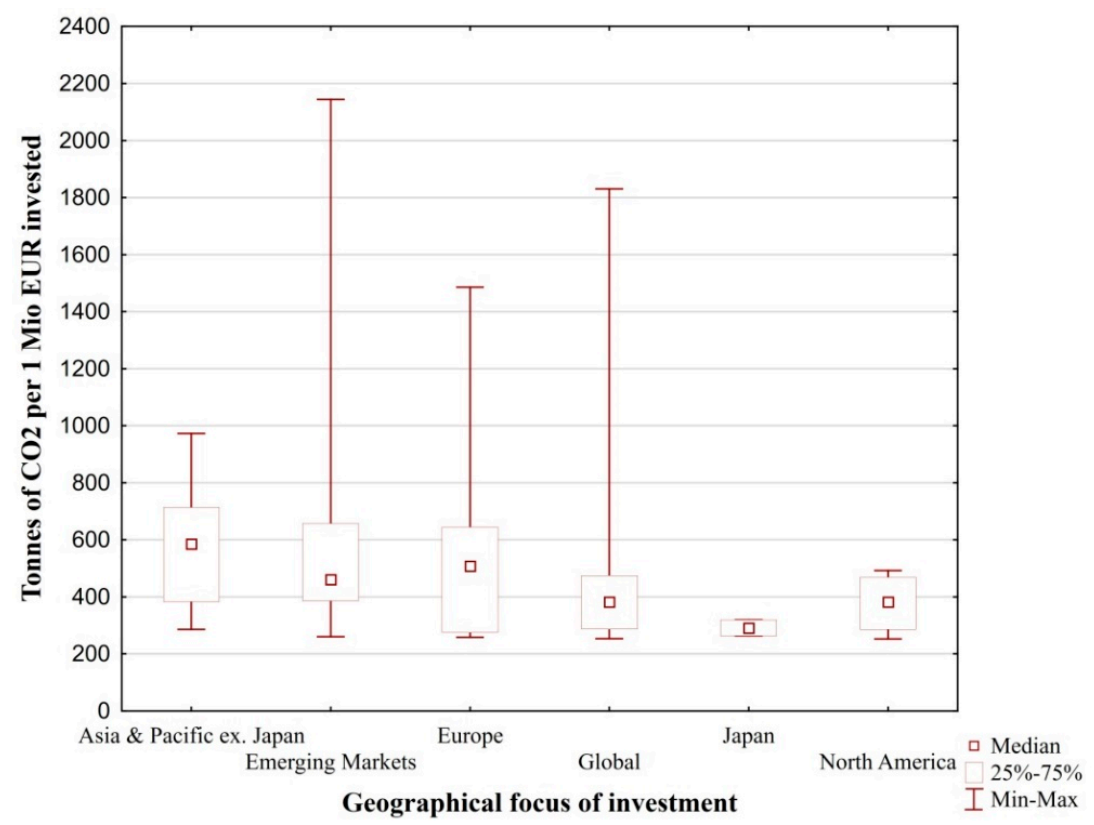

Figure A1. Relative carbon footprint for selected carbon intensive funds. 


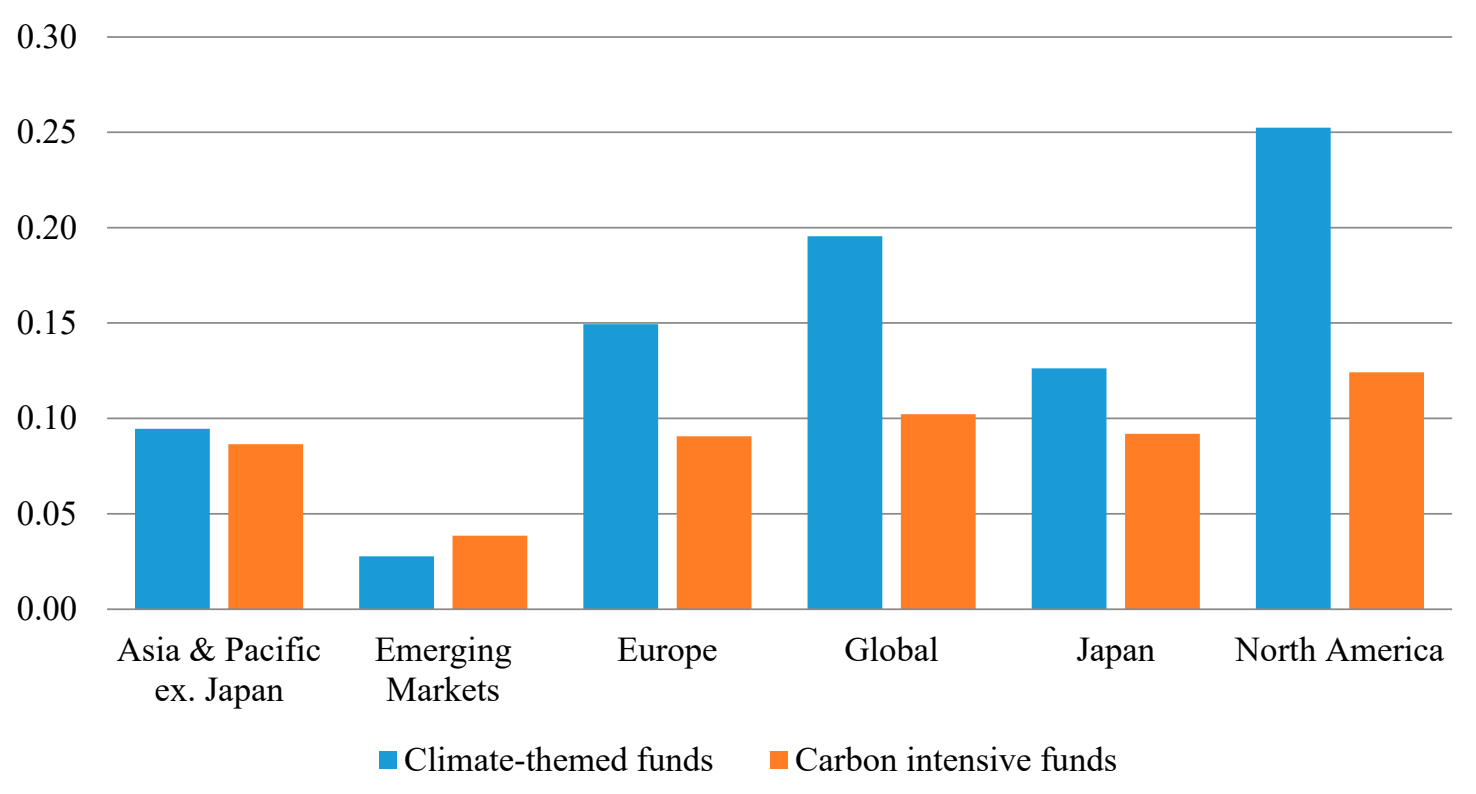

Figure A2. Sharpe ratio for equal-weighted portfolios of climate-themed funds and carbon intensive funds.

Table A2. Relative performance of carbon intensive portfolios.

\begin{tabular}{|c|c|c|c|c|c|c|}
\hline & $\begin{array}{c}\text { Asia \& Pacific } \\
\text { ex. Japan }\end{array}$ & $\begin{array}{l}\text { Emerging } \\
\text { Markets }\end{array}$ & Europe & Global & Japan & $\begin{array}{l}\text { North } \\
\text { America }\end{array}$ \\
\hline \multicolumn{7}{|c|}{ Panel A: CAPM model } \\
\hline Alpha & 0.0024 & 0.0017 & 0.0028 & 0.0002 & 0.0020 & $-0.0032^{* *}$ \\
\hline Market & $0.5643^{* * *}$ & $0.8583^{* * *}$ & $0.6902^{* * *}$ & $0.7806^{* * *}$ & $1.1286^{* * *}$ & $1.0842^{* * *}$ \\
\hline Observations & 115 & 115 & 115 & 115 & 115 & 115 \\
\hline$R^{2}$ & 0.686 & 0.929 & 0.751 & 0.842 & 0.709 & 0.876 \\
\hline \multirow[t]{2}{*}{ Adj. $R^{2}$} & 0.684 & 0.928 & 0.749 & 0.840 & 0.706 & 0.875 \\
\hline & $\begin{array}{l}\text { Asia \& Pacific } \\
\text { ex. Japan }\end{array}$ & $\begin{array}{l}\text { Emerging } \\
\text { Markets }\end{array}$ & Europe & Global & Japan & $\begin{array}{c}\text { North } \\
\text { America }\end{array}$ \\
\hline \multicolumn{7}{|c|}{ Panel B: Four-Factor Model } \\
\hline Alpha & 0.0030 & $0.0018 *$ & 0.0032 & 0.0000 & 0.0029 & -0.0015 \\
\hline Market & $0.5661 * * *$ & $0.8439 * * *$ & $0.6865^{* * *}$ & $0.7893^{* * *}$ & $1.1067^{* * *}$ & $0.9881^{* * *}$ \\
\hline SMB & 0.0388 & 0.0360 & -0.1351 & $0.1708^{* *}$ & -0.0751 & $0.4213^{* * *}$ \\
\hline HML & -0.1050 & 0.1093 * & -0.0665 & -0.0517 & 0.2503 * & 0.0622 \\
\hline WML & -0.0048 & -0.0276 & -0.0470 & 0.0300 & -0.0907 & -0.0665 \\
\hline Observations & 115 & 115 & 115 & 115 & 115 & 115 \\
\hline$R^{2}$ & 0.692 & 0.931 & 0.755 & 0.848 & 0.739 & 0.919 \\
\hline Adj. $R^{2}$ & 0.680 & 0.928 & 0.746 & 0.843 & 0.729 & 0.916 \\
\hline
\end{tabular}

Note: This table reports estimates for the equally weighted portfolios. $* * * * *$, and $*$ indicate statistical significance at the $1 \%, 5 \%$, and $10 \%$ levels, respectively. Standard errors are corrected for autocorrelation and heteroscedasticity following Newey and West [78]. 
Table A3. Industry analysis of carbon intensive portfolios.

\begin{tabular}{|c|c|c|c|c|c|c|}
\hline & $\begin{array}{c}\text { Asia \& Pacific } \\
\text { ex. Japan }\end{array}$ & $\begin{array}{l}\text { Emerging } \\
\text { Markets }\end{array}$ & Europe & Global & Japan & $\begin{array}{l}\text { North } \\
\text { America }\end{array}$ \\
\hline \multicolumn{7}{|c|}{ Panel A: Equal-Weighted Portfolio } \\
\hline Consumer Discretionary & $0.1273 *$ & 0.0532 & $0.1971^{* * *}$ & $0.1273 *$ & $0.0799 * *$ & $0.1955^{* *}$ \\
\hline Consumer Staples & -0.1471 & 0.0520 & 0.0376 & -0.1471 & $0.1829 * * *$ & -0.0710 \\
\hline Energy & $0.1849 * *$ & $0.2048^{* * *}$ & $0.0800^{* * *}$ & $0.1849 * *$ & $0.0387 * * *$ & $0.2769 * * *$ \\
\hline Health Care & 0.0724 & 0.0644 & 0.0093 & 0.0724 & -0.0274 & $0.1936^{* * *}$ \\
\hline Industrials & $0.3051 * *$ & 0.0078 & $0.1413^{* *}$ & $0.3051 * *$ & $0.2751^{* * *}$ & 0.1426 * \\
\hline Information Technology & $0.1305 *$ & $0.1631 * * *$ & 0.0054 & $0.1305 *$ & $0.1832 * * *$ & $0.0991^{* * *}$ \\
\hline Material & -0.0870 & 0.0279 & $0.1483^{* * *}$ & -0.0870 & 0.0424 & 0.0263 \\
\hline Real Estate & -0.0346 & 0.0225 & 0.0143 & -0.0346 & $0.0346 *$ & 0.0695 \\
\hline Telecommunication Services & -0.0620 & -0.0298 & 0.0284 & -0.0620 & $0.0426^{* *}$ & -0.0639 \\
\hline Adj. $R^{2}$ & 0.757 & 0.929 & 0.939 & 0.757 & 0.983 & 0.921 \\
\hline
\end{tabular}

Note: This table reports estimates for the equally weighted portfolios. ${ }^{* * *},{ }^{* *}$, and * indicate statistical significance at the $1 \%, 5 \%$, and $10 \%$ levels, respectively. Standard errors are corrected for autocorrelation and heteroscedasticity following Newey and West [78].

\section{References}

1. United Nations. United Nations Paris Agreement; 12 December 2015, C.N.63.2016.TREATIES-XXVII.7; United Nations: Paris, France, 2015.

2. Bieliński, T.; Mosionek-Schweda, M. Green Bonds as a Financial Instrument for Environmental Projects Funding. Unia Eur. 2018, 1, 13-21.

3. Auer, B.R.; Schuhmacher, F. Do socially (ir)responsible investments pay? New evidence from international ESG data. Q. Rev. Econ. Financ. 2016, 59, 51-62. [CrossRef]

4. Renneboog, L.; Ter Horst, J.; Zhang, C. Socially responsible investments: Institutional aspects, performance, and investor behavior. J. Bank. Financ. 2008, 32, 1723-1742. [CrossRef]

5. Hamilton, S.; Jo, H.; Statman, M. Doing Well While Doing Good? The Investment Performance of Socially Responsible Mutual Funds. Financ. Anal. J. 1993, 49, 62-66. [CrossRef]

6. Kreander, N.; Gray, R.H.; Power, D.M.; Sinclair, C.D. The financial performance of European ethical funds 1996-1998. J. Account. Financ. 2002, 1, 1-22.

7. Bhargava, R.; Gallo, J.G.; Swanson, P.E. The Performance, Asset Allocation, and Investment Style of International Equity Managers. Rev. Quant. Financ. Account. 2001, 17, 377-395. [CrossRef]

8. Solnik, B.H. Why not diversify internationally rather than domestically? Financ. Anal. J. 1995, 51, 89-94. [CrossRef]

9. Florida, P.; Roulac, S.E. Measuring the effectiveness of geographical diversification. J. Real Estate Portf. Manag. 2007, 13, 29-44.

10. Cavaglia, S.; Moroz, V. Cross-Industry, Cross-Country Allocation. Financ. Anal. J. 2002, 58, 78-97. [CrossRef]

11. Ramos, S.B. A Model of Geographical and Industrial Diversification. 2003; unpublished manuscript.

12. Heston, L.S.; Rouwenhorst, G.K. Industry and Country Effects in International Stock Returns. J. Portf. Manag. 1995, 21, 53-58. [CrossRef]

13. Coval, J.D.; Moskowitz, T.J. The geography of investment: Informed trading and asset prices. J. Political Econ. 2001, 109, 811-841. [CrossRef]

14. Ehling, P.; Ramos, S.B. Geographic versus industry diversification: Constraints matter. J. Empir. Financ. 2006, 13, 396-416. [CrossRef]

15. Lessard, D.R. World, national, and industry factors in equity returns. J. Financ. 1974, 29, 379-391. [CrossRef]

16. Cavaglia, S.; Brightman, C.; Aked, M. The Increasing Importance of Industry Factors. Financ. Anal. J. 2000, 56, 41-54. [CrossRef]

17. The Notre Dame Global Adaptation Initiative (ND-GAIN). Available online: https://gain.nd.edu/our-work/ country-index/ (accessed on 6 December 2019). 
18. Carbon Screening Services-YourSRI-Socially Responsible Investments. Available online: https://yoursri. com/services/paid-services/carbon-screening-services (accessed on 3 December 2019).

19. Bollen, N.P.B. Mutual Fund Attributes and Investor Behavior. J. Financ. Quant. Anal. 2007, 42, 683-708. [CrossRef]

20. Latinovic, M.; Obradovic, T. The Performance of Socially Responsible Investments. Entrep. Bus. Econ. Rev. 2013, 1, 29-39. [CrossRef]

21. Chegut, A.; Schenk, H.; Scholtens, B. Assessing SRI fund performance research: Best practices in empirical analysis. Sustain. Dev. 2011, 19, 77-94. [CrossRef]

22. Sauer, D.A. The impact of social-responsibility screens on investment performance: Evidence from the Domini 400 social index and Domini Equity Mutual Fund. Rev. Financ. Econ. 1997, 6, 137-149. [CrossRef]

23. Preston, L.E.; O'Bannon, D.P. The Corporate Social-Financial Performance Relationship. A typology and Analysis. Bus. Soc. 1997, 36, 419-429. [CrossRef]

24. Derwall, J.; Guenster, N.; Bauer, R.; Koedijk, K. The Eco-Efficiency Premium Puzzle. CFA Dig. 2005, 35, 63-64. [CrossRef]

25. Derwall, J.; Koedijk, K. Socially responsible fixed-income funds. J. Bus. Financ. Account. 2009, 36, $210-229$. [CrossRef]

26. Durán-Santomil, P.; Otero-González, L.; Correia-Domingues, R.H.; Reboredo, J.C. Does Sustainability Score Impact Mutual Fund Performance? Sustainability 2019, 11, 2972. [CrossRef]

27. Girard, E.; Rahman, H.; Stone, B.A. Socially Responsible Investments: Goody-Two-Shoes or Bad to the Bone? J. Investig. 2007, 16, 96-110. [CrossRef]

28. Chang, C.E.; Nelson, W.A.; Witte, H.D. Do green mutual funds perform well? Manag. Res. Rev. 2012, 35, 693-708. [CrossRef]

29. Eichholtz, P.; Kok, N.; Yonder, E. Portfolio greenness and the financial performance of REITs. J. Int. Money Financ. 2012, 31, 1911-1929. [CrossRef]

30. Silva, F.; Cortez, M.C. The performance of US and European green funds in different market conditions. J. Clean. Prod. 2016, 135, 558-566. [CrossRef]

31. Varma, A.; Nofsinger, J.R. Socially Responsible Funds and Market Crises. J. Bank. Financ. 2012, 48, $180-193$. [CrossRef]

32. Areal, N.; Cortez, M.C.; Silva, F. The conditional performance of US mutual funds over different market regimes: Do different types of ethical screens matter? Financ. Mark. Portf. Manag. 2013, 27, 397-429. [CrossRef]

33. Muñoz, F.; Vargas, M.; Marco, I. Environmental Mutual Funds: Financial Performance and Managerial Abilities. J. Bus. Ethics 2014, 124, 551-569. [CrossRef]

34. Ibikunle, G.; Steffen, T. European Green Mutual Fund Performance: A Comparative Analysis with their Conventional and Black Peers. J. Bus. Ethics 2017, 145, 337-355. [CrossRef]

35. Jin, J.; Han, L. Assessment of Chinese green funds: Performance and industry allocation. J. Clean. Prod. 2018, 171, 1084-1093. [CrossRef]

36. Bauer, R.; Koedijk, K.; Otten, R. International evidence on ethical mutual fund performance and investment style. J. Bank. Financ. 2005, 29, 1751-1767. [CrossRef]

37. Bauer, R.; Derwall, J.; Otten, R. The ethical mutual fund performance debate: New evidence from Canada. J. Bus. Ethics 2007, 70, 111-124. [CrossRef]

38. Signori, S. Ethical (SRI) funds in Italy: A review. Bus. Ethics Eur. Rev. 2009, 18, 145-164. [CrossRef]

39. Cortez, M.C.; Silva, F.; Areal, N. The Performance of European Socially Responsible Funds. J. Bus. Ethics 2009, 87, 573-588. [CrossRef]

40. Schröder, M. The performance of socially responsible investments: Investment funds and indices. Financ. Mark. Portf. Manag. 2004, 18, 122-142. [CrossRef]

41. Kreander, N.; Gray, R.H.; Power, D.M.; Sinclair, C.D. Evaluating the Performance of Ethical and Non-ethical Funds: A Matched Pair Analysis. J. Bus. Financ. Account. 2005, 32, 65-71. [CrossRef]

42. Basso, A.; Funari, S. DEA models with a constant input for SRI mutual funds with an application to European and Swedish funds. Int. Trans. Oper. Res. 2014, 21, 979-1000. [CrossRef]

43. Pena, J.; Cortez, M.C. Social Screening and Mutual Fund Performance: International Evidence. 2017; unpublished work. 
44. Leite, C.; Cortez, M.C.; Silva, F.; Adcock, C. The performance of socially responsible equity mutual funds: Evidence from Sweden. Bus. Ethics Eur. Rev. 2018, 27, 108-126. [CrossRef]

45. Sandberg, J.; Juravle, C.; Hedesström, T.M.; Hamilton, I. The heterogeneity of socially responsible investment. J. Bus. Ethics 2009, 87, 519-533. [CrossRef]

46. Global Sustainable Investment Alliance. Global Sustainable Investment Review 2018; Global Sustainable Investment Alliance: Brussels, Belgium, 2019.

47. European SRI Study EUROSIF. Available online: http://www.eurosif.org/wp-content/uploads/2018/11/ European-SRI-2018-Study.pdf (accessed on 6 December 2019).

48. YourSRI-Socially Responsible Investments. Available online: https://yoursri.com/ (accessed on 30 July 2019).

49. Kenneth, R. French-Data Library. Available online: https://mba.tuck.dartmouth.edu/pages/faculty/ken. french/data_library.html (accessed on 3 October 2019).

50. Climetrics -CDP. Available online: https://www.cdp.net/en/investor/climetrics/ (accessed on 3 December 2019).

51. Hoepner, A.G.F.; Schopohl, L. On the Price of Morals in Markets: An Empirical Study of the Swedish AP-Funds and the Norwegian Government Pension Fund. J. Bus. Ethics 2018, 151, 665-692. [CrossRef]

52. Hong, H.; Kacperczyk, M. The price of sin: The effects of social norms on markets. J. Financ. Econ. 2009, 93, 15-36. [CrossRef]

53. Leite, P.; Cortez, M.C. The performance of European SRI funds investing in bonds and their comparison to conventional funds. Investig. Anal. J. 2018, 47, 65-79. [CrossRef]

54. Omri, A.; Soussou, K.; Ben Sedrine Goucha, N. On the post-financial crisis performance of Islamic mutual funds: The case of Riyad funds. Appl. Econ. 2019, 51, 1929-1946. [CrossRef]

55. Salaber, J. Religion and returns in Europe. Eur. J. Political Econ. 2013, 32, 149-160. [CrossRef]

56. Trinks, P.J.; Scholtens, B. The Opportunity Cost of Negative Screening in Socially Responsible Investing. J. Bus. Ethics 2017, 140, 193-208. [CrossRef]

57. Zaremba, A. The Cross Section of Country Equity Returns: A Review of Empirical Literature. J. Risk Financ. Manag. 2019, 12, 165. [CrossRef]

58. Perez, K. Efektywność funduszy inwestycyjnych: Podejście techniczne i fundamentalne; Difin: Warszawa, Poland, 2012; ISBN 9978-83-7641-703-5.

59. Sharpe, W.F. Mutual Fund Performance. Source J. Bus. 1966, 39, 119-138. [CrossRef]

60. Dopierała, Ł. Indywidualne konta emerytalne prowadzone przez zakłady ubezpieczeń: Efektywność inwestycyjna $i$ zasady funkcjonowania; Wydawnictwo Uniwersytetu Gdańskiego: Gdańsk, Poland, 2018; ISBN 9788378656906.

61. Kabir, S.H.; Masih, A.M.M.; Bacha, O.I. Risk-Return Profiles of Islamic Equities and Commodity Portfolios in Different Market Conditions. Emerg. Mark. Financ. Trade 2017, 53, 1477-1500. [CrossRef]

62. Alwi, S.; Ahmad, R.; Zura Amir Hashim, I.; Mohd Naim, N. Investigating the Islamic and Conventional Mutual Fund Performance: Evidence From Malaysia Equity Market. J. Mod. Account. Audit. 2019, 15, 371-384.

63. Sortino, F.A.; Price, L.N. Performance Measurement in a Downside Risk Framework. J. Investig. 1994, 3, 59-64. [CrossRef]

64. Shadwick, W.F.; Keating, C. A Universal Performance Measure. J. Perform. Meas. 2002, 6, 59-84.

65. Young, T. Calmar ratio: A smoother tool. Future Mag. 1991, 20, 40.

66. Kruskal, W.H.; Wallis, W.A. Use of Ranks in One-Criterion Variance Analysis. J. Am. Stat. Assoc. 1952, 47, 583. [CrossRef]

67. Siegel, S.; Castellan, N.J., Jr. Non-Parametric Statistics for the Behavioural Sciences; MacGraw Hill International: New York, NY, USA, 1988; pp. 213-214.

68. Fabregat-Aibar, L.; Barberà-Mariné, M.G.; Terceño, A.; Pié, L. A Bibliometric and Visualization Analysis of Socially Responsible Funds. Sustainability 2019, 11, 2526. [CrossRef]

69. Sharpe, W.F. Capital Asset Prices: A Theory of Market Equilibrium under Conditons of Risk. J. Financ. 1964, $19,425-442$.

70. Jensen, M.C. The Performance of Mutual Funds in the Period 1945-1964. J. Financ. 1968, 23, 389-416. [CrossRef]

71. Fama, E.F.; French, K.R. Common risk factors in the returns on stocks and bonds. J. Financ. Econ. 1993, 33, 3-56. [CrossRef]

72. Carhart, M.M. On Persistence in Mutual Fund Performance. J. Financ. 1997, 52, 57-82. [CrossRef] 
73. GICS—Global Industry Classification Standard-MSCI. Available online: https://www.msci.com/gics (accessed on 10 November 2019).

74. Benson, K.L.; Brailsford, T.J.; Humphrey, J.E. Do socially responsible fund managers really invest differently? J. Bus. Ethics 2006, 65, 337-357. [CrossRef]

75. Eling, M.; Schuhmacher, F. Does the choice of performance measure influence the evaluation of hedge funds? J. Bank. Financ. 2007, 31, 2632-2647. [CrossRef]

76. Ornelas, J.R.H.; Silva Júnior, A.F.; Fernandes, J.L.B. Yes, the choice of performance measure does matter for ranking of us mutual funds. Int. J. Financ. Econ. 2012, 17, 61-72. [CrossRef]

77. Teo, M. The Geography of Hedge Funds. Rev. Financ. Stud. 2009, 22, 3531-3561. [CrossRef]

78. Newey, W.K.; West, K.D. A Simple, Positive Semi-Definite, Heteroskedasticity and Autocorrelation Consistent Covariance Matrix. Econometrica 1987, 55, 703. [CrossRef]

79. Zaremba, A. Country selection strategies based on value, size and momentum. Investig. Anal. J. 2015, 44, 171-198. [CrossRef]

80. Zaremba, A. The momentum effect in country-level stock market anomalies. Econ. Res. Istraživanja 2018, 31, 703-721. [CrossRef]

81. Becchetti, L.; Ciciretti, R.; Dalò, A.; Herzel, S. Socially responsible and conventional investment funds: Performance comparison and the global financial crisis. Appl. Econ. 2015, 47, 2541-2562. [CrossRef]

82. Ielasi, F.; Rossolini, M. Responsible or Thematic? The True Nature of Sustainability-Themed Mutual Funds. Sustainability 2019, 11, 3304. [CrossRef]

83. Busse, J.A.; Tong, Q. Mutual Fund Industry Selection and Persistence. Rev. Asset Pricing Stud. 2012, 2, 245-274. [CrossRef]

84. Ferson, W.E.; Schadt, R.W. Measuring Fund Strategy and Performance in Changing Economic Conditions. J. Financ. 1996, 51, 425-461. [CrossRef]

85. Christopherson, J.A.; Ferson, W.E.; Glassman, D.A. Conditioning Manager Alphas on Economic Information: Another Look at the Persistence of Performance. Rev. Financ. Stud. 1998, 11, 111-142. [CrossRef] 